\title{
Low-E Storm Windows: Market Assessment and Pathways to Market Transformation
}

KA Cort

June 2013

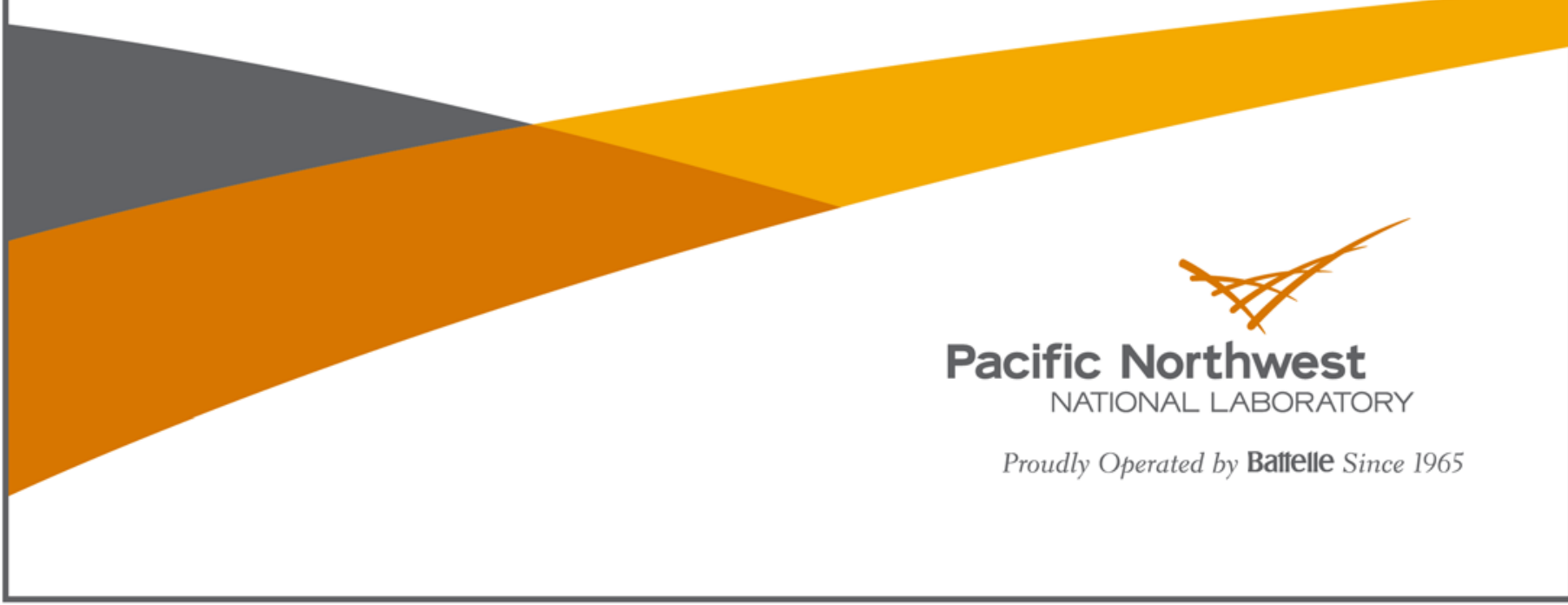




\title{
DISCLAIMER
}

This report was prepared as an account of work sponsored by an agency of the United States Government. Neither the United States Government nor any agency thereof, nor Battelle Memorial Institute, nor any of their employees, makes any warranty, express or implied, or assumes any legal liability or responsibility for the accuracy, completeness, or usefulness of any information, apparatus, product, or process disclosed, or represents that its use would not infringe privately owned rights. Reference herein to any specific commercial product, process, or service by trade name, trademark, manufacturer, or otherwise does not necessarily constitute or imply its endorsement, recommendation, or favoring by the United States Government or any agency thereof, or Battelle Memorial Institute. The views and opinions of authors expressed herein do not necessarily state or reflect those of the United States Government or any agency thereof.

\author{
PACIFIC NORTHWEST NATIONAL LABORATORY \\ operated by \\ BATTELLE \\ for the \\ UNITED STATES DEPARTMENT OF ENERGY \\ under Contract DE-AC05-76RL01830
}

Printed in the United States of America
Available to DOE and DOE contractors from the Office of Scientific and Technical Information,
P.O. Box 62, Oak Ridge, TN 37831-0062;
ph: (865) 576-8401
fax: $(865) 576-5728$
email: reports@adonis.osti.gov
Available to the public from the National Technical Information Service
5301 Shawnee Rd., Alexandria, VA 22312 ph: (800) 553-NTIS (6847)
email: orders@ntis.gov $<$ http://www.ntis.gov/about/form.aspx $>$
Online ordering: http://www.ntis.gov

This document was printed on recycled paper. 


\section{Low-E Storm Windows: Market Assessment and Pathways to Market Transformation}

KA Cort

June 2013

Prepared for

the U.S. Department of Energy

under Contract DE-AC05-76RL01830

Pacific Northwest National Laboratory

Richland, Washington 99352 



\section{Executive Summary}

Laboratory and field studies sponsored by the U.S. Department of Energy (DOE) demonstrate that the use of low-emissivity (low-e) storm windows can lead to significant heating and cooling energy savings in homes. This report examines the market for low-e storm windows based on market data, case studies, and recent experience with weatherization deployment programs. It uses information from interviews conducted with DOE researchers and industry partners involved in case studies and early deployment efforts related to low-e storm windows. In addition, this study examines potential barriers to market acceptance, assesses the market and energy savings potential, and identifies opportunities to transform the market for low-e storm windows and overcome market adoption barriers.

Based on laboratory testing, case studies, and climate-based modeled energy savings, the installation of low-e storm windows is estimated to reduce heating and cooling consumption by 12 to 33\% in residential homes. Individual home savings would depend on the overall condition of existing windows and home as well as climate conditions. Based on these heating and cooling saving ranges, low-e storm windows have a technical potential energy savings - that is, the energy savings that would result if all low-performing windows were covered with low-e storm windows - ranging from 0.7 to 1.96 quadrillion Btus primary (source) energy. Of this technical potential, this study estimates that market adoption of low-e storm windows could reasonably achieve savings of 140 trillion Btus of primary energy annually by 2025, assuming DOE implements a number of market transformation activities directed toward low-e storm window market adoption.

To assess the marketability and market adoption potential of low-e storm windows, this study examines and characterizes the benefits and costs of the technology, the size and characteristics of likely target markets, the potential pathways to reach these markets, possible market barriers, and the likelihood of overcoming these barriers. A number of promising market transformation pathways are identified including existing weatherization assistance programs, utility energy-efficiency incentive programs, federally sponsored energyefficiency retrofit programs, standards and rating organizations, and federal building energy-efficiency mandates and programs. By working with storm window manufacturers, installers, energy-efficiency consortiums, and the Federal Energy Management Program, the U.S. Department of Energy's Building America program could implement a number of targeted outreach, education, and technical assistance programs to help effectively transform the

Target Market:

Existing residential households with lowperforming windows. Selected commercial buildings (e.g., nursing homes, dormitories, and small commercial buildings) with low-performing single-pane windows.

Target Application:

Reduce heating and cooling loads by installing low-e storm windows over low-performing windows.

\section{Energy Savings:}

Projected heating and cooling savings range from $12-33 \%$ per household, depending on baseline conditions and climate factors.

\section{National Impact:}

Technical potential heating and cooling savings ranging from 0.7 to 1.96 primary (source) quadrillion Btus. Annual market potential achievable in 10 years is estimated at 140 trillion primary Btus of energy.

market for low-e storm windows and have a measurable impact on reducing residential energy consumption over time. 



\section{Acknowledgments}

The author would like to thank Tom Culp who assisted in the preparation of this document by providing input, collecting data and providing comments and suggestions on the report.

The author would like to thank Todd Stratmoen and David Bailey of Larson Manufacturing Company and John Siegel of Quanta Technologies, who took time from their schedules to be interviewed for this report. 



\section{Acronyms and Abbreviations}

$\begin{array}{ll}\text { AEO } & \text { Annual Energy Outlook } \\ \text { Building America } & \text { Building America } \\ \text { BB } & \text { Better Building } \\ \text { BTP } & \text { Building Technologies Program } \\ \text { CBECS } & \text { Commercial Buildings Energy Consumption Survey } \\ \text { CEE } & \text { Consortium for Energy Efficiency } \\ \text { Cfm } & \text { cubic feet per minute } \\ \text { CSI } & \text { Codes and Standards Innovation } \\ \text { DOE } & \text { U.S. Department of Energy } \\ \text { DSIRE } & \text { Database of State Incentives for Renewables and Efficiency } \\ \text { EIA } & \text { Energy Information Administration } \\ \text { EPA } & \text { U.S. Environmental Protection Agency } \\ \text { ET } & \text { emerging technologies } \\ \text { EUI } & \text { energy use intensity } \\ \text { HPwES } & \text { Home Performance with Energy Star } \\ \text { HUD } & \text { U.S. Department of Housing and Urban Development } \\ \text { HVAC } & \text { heating, ventilation, and air-conditioning } \\ \text { IECC } & \text { International Energy Conservation Code } \\ \text { IR } & \text { infrared } \\ \text { LBNL } & \text { Lawrence Berkeley National Laboratory } \\ \text { LIHEAP } & \text { Low-Income Home Energy Assistance Program } \\ \text { Low-e } & \text { low emissivity } \\ \text { MOU } & \text { Memorandum of Understanding } \\ \text { NAHB } & \text { National Association of Home Builders } \\ \text { NEAT } & \text { National Energy Audit Tool } \\ \text { RECS } & \text { Residential Energy Consumption Survey } \\ \text { TBD } & \text { To be determined } \\ & \end{array}$





\section{Contents}

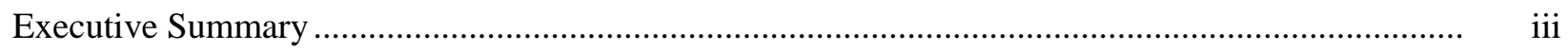

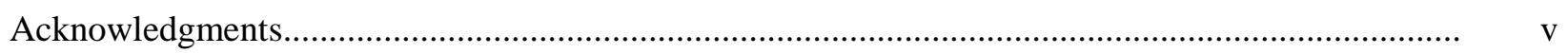

Acronyms and Abbreviations .......................................................................................................... vii

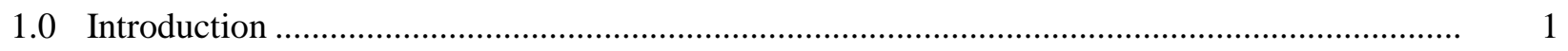

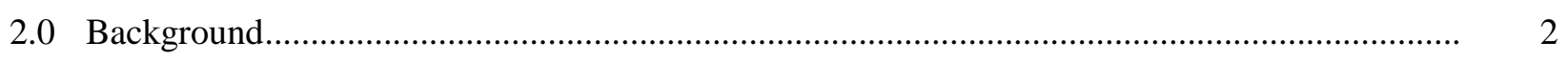

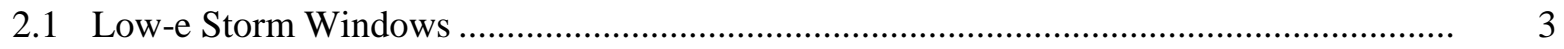

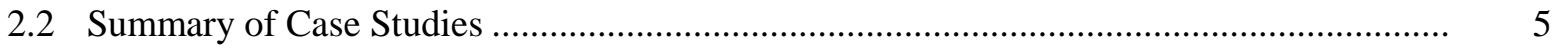

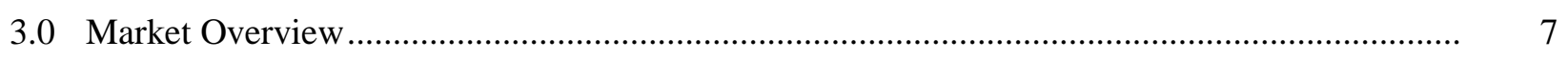

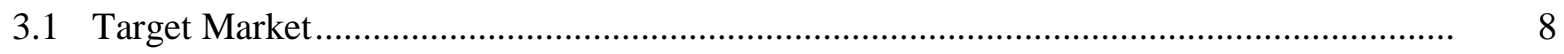

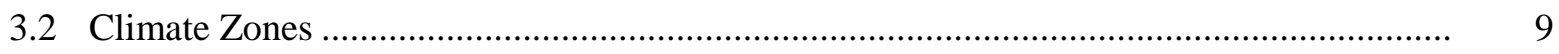

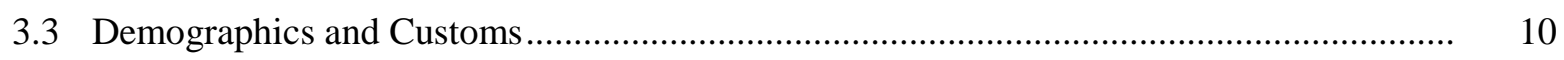

Non-Residential Applications ..................................................................................... 10

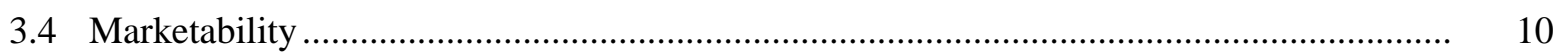

3.5 Energy Consumption and Savings Potential ................................................................. 12

4.0 Market Transformation Opportunities ..................................................................................... 13

4.1 Home Performance Upgrades ..................................................................................... 14

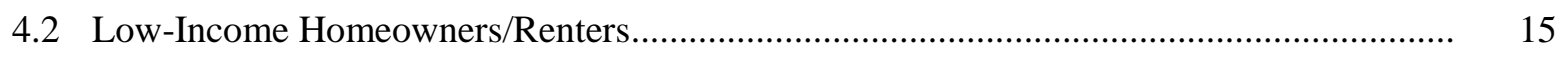

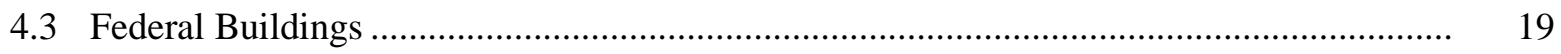

4.4 Commercial Buildings.............................................................................................. 20

4.5 Supply Chain for Market Transformation.................................................................... 20

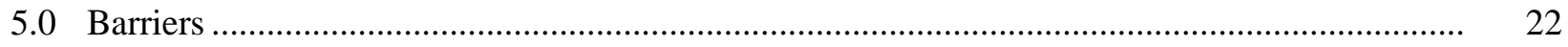

5.1 Potential Market Barriers ......................................................................................... 22

5.2 Assessment of Potential Show-Stoppers ........................................................................ 23

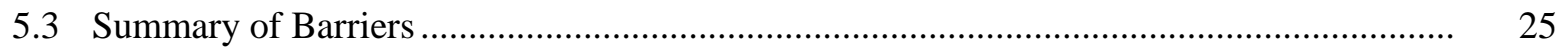

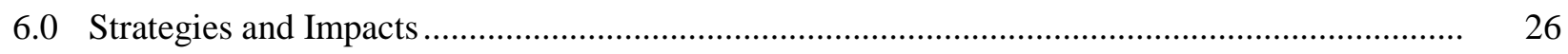

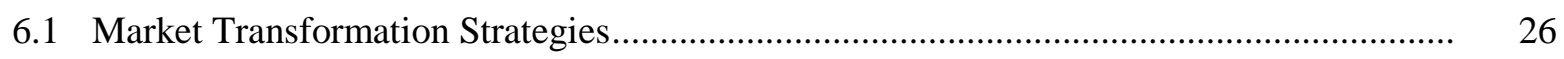

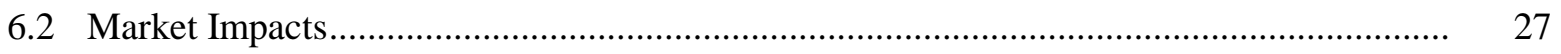

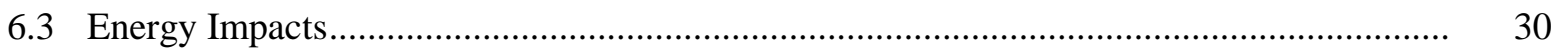

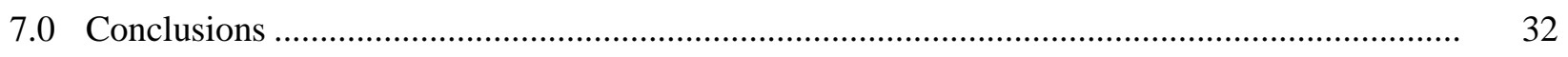

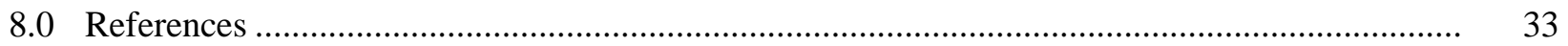




\section{Figures}

2.1 These three photos demonstrate the evolution of the storm window: traditional seasonal storm panels, aluminum-framed self-storing storm window and screen, and high-performance low-e storm windows

2.2 The low-e coating reflects infrared heat back into the home, reducing heating losses................. 3

3.1 Percentage of National Storm Window Sales (2012) estimated by the U.S. Census Division..... 8

3.2 Number of households with single-pane and double-pane clear by U.S. Census Division .......... 9

4.1 Supply chain for Building America's low-e storm windows research and deployment.............. 13

4.2 Supply chain (including contact points with end customer) .................................................... 21

6.1 Estimated annual low-e window sales with and without market transformation......................... 29

6.2 Energy savings for high, moderate, and low market scenarios................................................

\section{Tables}

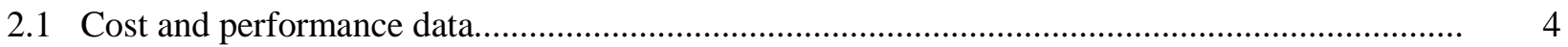

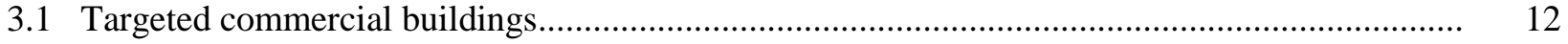

6.1 Barriers, strategies, and pathways to market transformation for low-e storm windows .............. 26

6.2 Size of market segment and potential pathways to market transformation ................................. 28 


\subsection{Introduction}

Residential buildings currently require approximately 9.5 quadrillion Btus of energy for heating and cooling, which accounts for over $40 \%$ of the primary energy consumed by homes. Windows are a major source of heating losses and gains in residential buildings. Despite this fact, approximately $40 \%$ of U.S. homes have single-pane windows, which are inherently inefficient and poor insulators. Thus, a tremendous opportunity exists to provide energy savings to a large segment of residences, most of which accommodate moderate- and low-income households. While the window industry has made many advances in energy efficiency over the last decade, the installation of low-emissivity (low-e) double-pane windows has largely been limited to new housing and major remodeling projects. The presence of singlepane windows in homes has persisted over the past two decades, despite the fact that approximately 30 million windows are replaced each year with higher performing, insulated windows. Window attachments (i.e., storm windows) can provide added insulation at significantly lower cost than replacing a window. Approximately 8 million ${ }^{1}$ storm windows are sold annually in the United States; however, most are clear glass and do not include a low-e coating for additional insulating performance. There is the potential to both convert the existing storm window market to higher performance low-e technology as well as appreciably increase the total market volume to retrofit more homes.

Field studies sponsored by the U.S. Department of Energy (DOE) have shown that the use of low-e storm windows can lead to significant heating and cooling energy savings in homes. This study examines the market for low-e storm windows based on market data, case studies, and recent experience with weatherization deployment programs. It uses information from interviews conducted with DOE researchers and industry partners involved in case studies, weatherization programs, and early deployment efforts related to low-e storm windows. In addition, this study examines potential barriers to market acceptance, assesses the market and energy savings potential, and identifies opportunities to transform the market for low-e storm windows and overcome market adoption barriers.

\footnotetext{
${ }^{1}$ Estimate based on American Architectural Manufacturers Association (AAMA) estimates as reported in 2009 Energy Data Book (EIA). AAMA estimates provided for 1990-2005 and trended downward based on industry input and information as well as the overall economic and construction and renovation trends during this period.
} 


\subsection{Background}

Low-e coated glass was first developed to improve the energy performance of new and replacement windows to help building enclosures reduce heat loss that would leak out of less efficient windows. Subsequently in the 1990s, DOE's Building Technologies Program (BTP) began exploring the concept of applying low-e coatings to storm windows. Development and laboratory testing efforts were primarily led by researchers at Lawrence Berkeley National Laboratory (LBNL) (Klems 2003). Early field testing at the Mobile Window Thermal Test facility demonstrated that these low-e storm windows provided the same performance improvement as new low-e replacement windows. BTP's Emerging Technologies (ET) team continued supporting the development and field testing of low-e storm windows in collaboration with the NAHB Research Center and Utilivate Technologies (Drumheller et al. 2007). The ET team also supported demonstrations of the technology with case studies and initiated deployment efforts by including low-e storm windows as part of its volume purchase market transformation program (Parker et al. 2013). ET continued funding field case studies and educational programs (Quanta Technologies 2013), and initiating a pilot program to integrate low-e storm windows as a qualified weatherization measure in Pennsylvania as part of DOE's Weatherization Assistance Program (WAP) (Krigger and Van der Meer 2011).

Low-e storm windows have now been commercially available on a wide-scale basis since 2009; thus, the focus of DOE's support is moving toward enabling the market transformation and deployment of lowe storm windows by confirming and validating the performance of the technology and identifying and overcoming technical and market barriers to adoption. This support is being provided through DOE's Building America (Building America) program, which serves as a catalyst to accelerate the residential building energy-efficiency market transformation and support increasing levels of cost-effective whole house energy savings. Market transformation requires collaboration between multiple parties.

Information for this market assessment was drawn from the experience of researchers and DOE industry partners participating in low-e storm windows case studies and pilot programs and from utility energyefficiency administrators participating in the Consortium for Energy Efficiency's (CEE's) window-related working groups.

In 2011, Pennsylvania became the first state weatherization program to explicitly integrate low-e storm windows into its list of priority weatherization measures. To assist in characterizing the low-e storm market and the Pennsylvania's weatherization experience for this report, interviews were conducted with three representatives from two manufacturers of low-e storm windows. ${ }^{2}$ Manufacturers provided information related to comparative experiences of low-e storm window sales and consumer/housing characteristics both within Pennsylvania's weatherization program and outside of the state. They also shared characteristics of typical end-use consumers, product and installation costs, installer and contractor training efforts, industry structure, and marketing efforts related to low-e storm windows. This information informed many of the conclusions drawn in this report related to market potential, market barriers, and possible pathways to transform the market for low-e storm windows.

\footnotetext{
${ }^{2}$ An interview with Todd Stratmoen and David Bailey of Larson Manufacturing Company was conducted over the phone on April 23, 2013 with e-mail correspondences following in April, May, and June 2013. A phone interview with John Siegel of Quanta Technologies was conducted on June 4, 2014.
} 


\subsection{Low-e Storm Window Technology}

A well-installed storm window, mounted on the outside or inside of a primary glass window (also referred to as prime window), can reduce heat loss and gains by improving the thermal efficiency of the window and reducing infiltration. In parts of the United States, storm windows are commonly used during the heating season. However, though storm windows are sometimes only used seasonally, they can be installed as permanent window attachments.

Traditional storm windows consisted of a single piece of clear glass (or plastic) in a wood or aluminum frame and were installed on the outside of an existing window. Modern storm windows can be operable or fixed in place and come in a variety of configurations and colors. Further, they typically have insert screens to allow for natural ventilation, tighter seals for less air leakage, and can be permanently mounted. Low-e storm windows look just like other modern storm windows (see Figure 2.1), but include a low-e pyrolytic coating that lowers the emissivity of glass, effectively reducing the U-factor (i.e., increasing the R-value) of the storm window (see Figure 2.2). The pyrolytic coat is a hard ceramic coating based on tin oxide that can withstand the elements without degrading or discoloring the window.

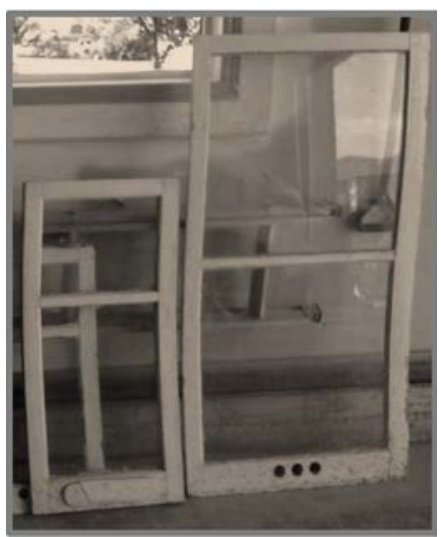

(a)

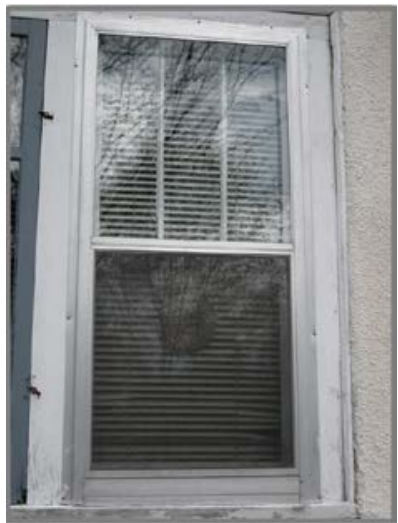

(b)

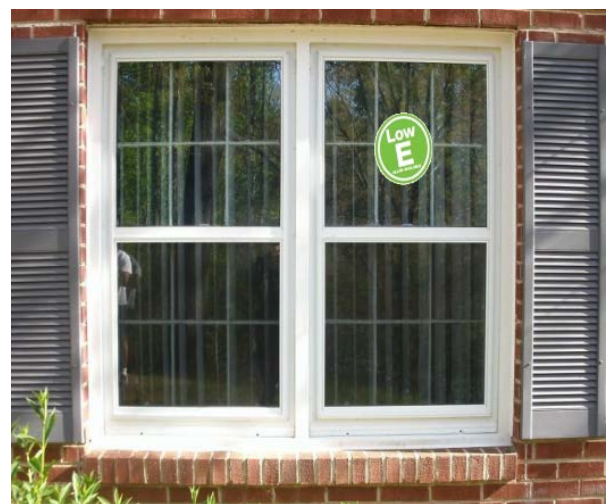

(c)

Figure 2.1. These three photos demonstrate the evolution of the storm window: (a) traditional seasonal storm panels, (b) aluminum-framed self-storing storm window and screen, and (c) high-performance low-e storm windows

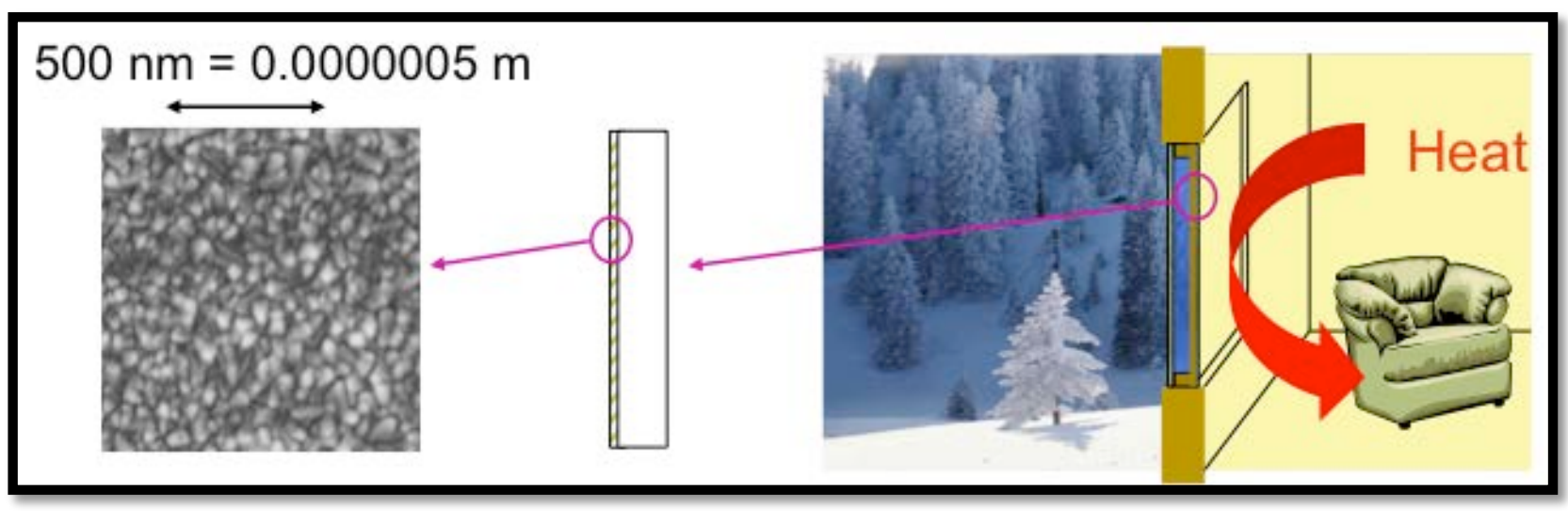

Figure 2.2. The low-e coating reflects infrared heat back into the home, reducing heating losses 
In general, storm window pricing varies by manufacturer, size, customization, and framing material. The price for a standard $3 \times 4.5 \mathrm{ft}$ storm window ranges from $\$ 50$ to $\$ 150$. Larson Manufacturing Company, the largest manufacturer and distributor of storm windows in the United States, sells its product through independent dealers and big-box home improvement stores (e.g., Lowes, Home Depot, and Menards). Larson currently sells storm windows with and without low-e coatings. The price premium for low-e storm windows is approximately 10 to 15\%. Larson's stock (i.e., not customized) $3 \times$ $4.5 \mathrm{ft}$ low-e storm window is available at Menards retail stores for $\$ 73 .^{3}$ Because of the wide variability in existing buildings and window styles, it is common for storm windows to be provided at custom sizes specific to each particular home. In general, the price for a low-e storm window at custom sizes ranges from $\$ 70$ to $\$ 150$ per window panel. Installation can be performed by the purchaser as a do-it-yourself project and requires approximately 20 to 30 minutes per storm window for the novice installer. Professional installation usually costs about $\$ 60$ per window, ${ }^{4}$ although this cost can be higher or lower depending on location.

Table 2.1 compares some of the cost and performance information for various window types and window attachments.

Table 2.1. Cost and performance data

\begin{tabular}{|c|c|c|c|c|}
\hline & $\begin{array}{l}\text { Single-Pane } \\
\text { Window }\end{array}$ & $\begin{array}{l}\text { Double-Pane } \\
\text { Replacement } \\
\text { window }\end{array}$ & Clear Storm Window & $\begin{array}{c}\text { Preliminary Low-E Storm } \\
\text { Window Data }\end{array}$ \\
\hline Cost range of window & -- & $\$ 200-\$ 500$ & $\$ 70-\$ 125$ & $\$ 80-\$ 150$ \\
\hline Installation cost & -- & $\begin{array}{l}\$ 100 \text { - } \$ 500 \text { per } \\
\text { window }\end{array}$ & $\begin{array}{c}\$ 2 \text { (DIY) to } \$ 60 \text { per } \\
\text { window }\end{array}$ & $\begin{array}{c}\$ 2 \text { (DIY) to } \$ 60 \text { per } \\
\text { window }\end{array}$ \\
\hline $\begin{array}{l}\text { SIR compared to single } \\
\text { pane }\end{array}$ & -- & $\begin{array}{l}<1 \text { (not qualified } \\
\text { for WX programs) }\end{array}$ & $\begin{array}{l}<1 \text { to } 1.2 \\
\text { (usually not qualified } \\
\text { for WX program) }\end{array}$ & $\begin{array}{c}1.3 \text { - } 3.2 \text { in central and } \\
\text { northern climates -- } \\
\text { qualifies for WX) }\end{array}$ \\
\hline $\begin{array}{l}\text { Average HVAC energy } \\
\text { cost savings compared to } \\
\text { single pane }\end{array}$ & & $11-35 \%$ & $5-20 \%$ & $12-33 \%$ \\
\hline U-factor $\left(B t u / h \mathrm{ft}^{2} \mathrm{~F}\right)$ & 0.88 & $0.30-0.35$ & 0.50 & $0.34-0.36$ \\
\hline SHGC & 0.63 & $0.25-0.30$ & 0.56 & $0.45-0.52$ \\
\hline Air leakage $\left(\mathrm{cfm} / \mathrm{ft}^{2}\right)$ & $1-4$ & $0.1-0.3$ & 0.3 & $0.1-0.3$ \\
\hline \multicolumn{5}{|c|}{$\begin{array}{l}\text { Note: Low-e storm window estimates based on case studies and preliminary findings from NEAT/RESFEN } \\
\text { regional analysis (See Section 2.2). All other ranges and estimates based on Consortium for Energy Efficiency } \\
\text { (CEE) windows working group consensus estimates (Hefty and Cort 2013). } \\
\text { DIY = do it yourself; HVAC = heating, ventilation, and air-conditioning; PA = Pennsylvania; SHGC = solar heat } \\
\text { gain coefficient; SIR = savings to investment ratio; WX = weatherization }\end{array}$} \\
\hline
\end{tabular}

\footnotetext{
${ }^{3}$ Information accessed June 13, 2013 at http://www.menards.com.

${ }^{4}$ Cost estimated from informal survey of contractors participating in energy-efficient upgrades and CEE working groups (Hefty and Cort 2013)
} 


\subsection{Summary of Case Studies}

A series of laboratory tests have proven that standard low-e storm windows save energy at the component level. The performance improvements have been validated with field tests and case studies supported by DOE's ET team. Tests and results are summarized in the following paragraphs.

Chicago Case Study. DOE partnered with the U.S. Department of Housing and Urban Development (HUD), NAHB Research Center, and LBNL to demonstrate actual savings in typical low-income houses in a cold climate (Chicago). It involved six actual occupied homes that were part of a weatherization program. The study included heating season energy monitoring data on the six homes which had low-e storm windows installed over single-pane, wood-framed windows. The study showed an average 21\% reduction in the overall home heating load, a 7\% reduction in the overall home air infiltration, and a simple payback of 4 to 5 years. However, because the study was performed in real homes, the data set was limited and variable due to home type and occupancy (Drumheller et al. 2007)

Infrared Camera Imaging. LBNL and Building Green conducted infrared (IR) imaging of low-e storm windows installed on the interior side of single-pane, wood-framed windows and compared the results with those from IR imaging of low-e replacement windows installed in an occupied home under winter heating conditions. The IR imaging was conducted at different air pressurizations to help visualize the effect of wind and air leakage on the thermal performance of both the storm windows and replacement windows. Compelling images showed that the low-e storm windows performed equivalent to, or better than, new double-pane replacement windows with low-e glass and argon gas fill (Hefty et al. 2013).

Atlanta Case Study. This ongoing field case study involves ten older homes near Atlanta, Georgia. Partners in the DOE-funded project included Quanta Technologies, Larson Manufacturing Company, the NAHB research center, AGC Flat Glass, and NSG-Pilkington. The study includes 2 years of energy monitoring on ten occupied homes near Atlanta that had low-e storm windows installed over single-pane, wood-framed windows. Monitoring has been conducted during both the heating and cooling seasons in Atlanta's mixed-humid climate. Three types of storm windows have been compared: clear glass, highsolar-gain low-e glass, and low-solar-gain low-e glass. Very preliminary results show a roughly $10 \%$ heating energy reduction and 8\% cooling reduction with the low-e storm windows; however the data are being analyzed further to clarify the average savings over the 2-year study period. In addition, blower door tests showed a significant reduction in whole home air leakage (i.e., 0 to $44 \%$, average $17 \%$ ). This study is ongoing, but similar to the Chicago study, the work was done as a demonstration study in real homes; thus the data are variable due to differences in home type, occupancy, and weather (Quanta Technologies 2013).

Philadelphia Multifamily Case Study. This ongoing field study involves multifamily apartment buildings in Philadelphia. Participants in the DOE-funded project include Quanta Technologies, Larson Manufacturing Company, the NAHB research center, AGC Flat Glass, and NSG-Pilkington. The study includes one year of energy monitoring on two large apartment buildings where existing, old clear storm windows over single-pane, metal-framed windows were replaced with modern low-e storm windows. As with the Atlanta study, blower door tests showed an average $10 \%$ reduction in overall apartment air leakage from use of the new low-E storm windows (or $3.3 \mathrm{cfm}_{50} / \mathrm{ft}^{2}$ of window area), whereas the old degraded storm windows showed almost no impact on air leakage (Quanta Technologies 2013). 
Field Air-Leakage Testing. This study by Steven Winter Associates and Quanta Technologies measured air-leakage reductions from the use of interior operable low-e storm windows in a multifamily building in the Bronx borough of New York City, New York. A field protocol was developed, based on a modified blower door test, to measure the effective leakage area before and after low-e storm windows were installed over windows with and without unit air conditioners. The effective leakage area was reduced by $77 \%$ for windows without air-conditioning units and by $95 \%$ for windows with airconditioning units. Steven Winter Associates estimated that this reduction in effective leakage area would reduce the building's total air changes per hour by an average of 35\% (Quanta Technologies 2013).

Lab Homes Testing. In a controlled whole building experiment using twin houses, the performance of low-e storm windows over double-pane clear glass windows was compared between the control and experiment (Widder 2013). This study is ongoing; however, preliminary heating season data (from 2week time period) have been collected for this research project funded by Building America. The preliminary results show an average of $10.3 \%$ whole house energy savings $( \pm 2.3 \%$ with $95 \%$ confidence). The heating, ventilation, and air-conditioning (HVAC) savings were $14.7 \% \pm 3.7 \%$. As the study progresses, more data will give this number more significance. ${ }^{5}$

In addition to the field tests and case studies, a DOE-funded joint effort ${ }^{6}$ including a 2010-2011 analysis conducted using the National Energy Audit Tool (NEAT), examining the benefits and costs of low-e storm windows in 37 model homes in Pennsylvania in four cities having 4700 to 6300 heating degree days. ${ }^{7}$ The results of that analysis estimated a savings-to-investment ratio of 1.4 to 2.2, which led the state of Pennsylvania to add low-e storm windows to its weatherization measure priority list. Following that effort, a 2012 analysis was conducted by Birch Point Consulting using RESFEN ${ }^{8}$ to estimate energy savings of low-e storm windows in 30 cities across 7 climate zones using two generic home types. Results ranged from $12 \%$ to $33 \%$ overall energy cost savings (Zalis, et. al. 2010).

\footnotetext{
${ }^{5}$ E-mail Correspondence from Sarah Widder, Program Lead for Low-e Storm Lab Home Testing, "LES Preliminary Heating Season Results,” April 10, 2013.

${ }^{6}$ Joint effort between DOE's BTP and DOE's Office of Weatherization and Intergovernmental Programs (WIP), Pennsylvania’s Department of Community and Economic Development, LBNL, Energetics, and Birch Point Consulting.

${ }^{7}$ Where heating degree days refers to difference between the mean temperature for the day and $65^{\circ} \mathrm{F}$ summed for every day in a year where the mean temperature is less than $65^{\circ} \mathrm{F}$.

${ }^{8}$ RESFEN is a residential energy efficient windows selection software tool developed by LBNL that helps determine sizing, shading, and thermal properties of new windows.
} 


\subsection{Market Overview}

Before installation of double-pane windows became common practice in northern climates in the 1970s and 1980s, single-pane windows were the standard. Many homes with single-pane windows used storm windows to provide thermal and some amount of air-infiltration benefit. These storm windows were often removed each summer for fresh air ventilation. In the early 1990s, a DOE-conducted residential survey estimated that approximately $40 \%$ of all windows were covered with some form of a storm window (DOE-EIA 1993). Over time, many storm windows would break or be removed for various reasons, thereby reducing the benefit of the storm window. Although no current data is available related to the number of storm window installations nationwide, the AAMA estimates that approximately 8 million ${ }^{9}$ storm windows are sold annually in the United States. Recent studies also suggest that today fewer households have storm windows in place than what was suggested in the 1993 survey, and that these numbers can vary widely by region. For example, a recent, regionally stratified residential baseline characterization survey in Michigan found that approximately $20 \%$ of surveyed single-family homes had installed storm windows and approximately 33\% of those households kept the storm windows installed on a temporary basis (Cadmus 2011). A recent study sponsored by the Northwest Energy Efficiency Alliance estimated that approximately $11 \%$ of the single-family homes in the northwestern states of Idaho, Montana, Oregon, and Washington had storm windows installed (Ecotope 2012).

Based on interviews with storm window manufacturers, typical consumers of storm windows are single-family homeowners. No particular demographic characteristics or income level characterizes customers; however, representatives from Larson Manufacturing Company estimated that approximately $80 \%$ of storm windows are installed as do-it-yourself home improvements and do not involve professional home improvement contractors. Although storm windows need to be customized to fit the primary window, over $50 \%$ of retail sales of storm windows are through big-box retailers; the rest are sold through independent dealers. Larson Manufacturing Company sells a portion of its storm windows through big-box home improvement chains and has recently begun to stock some of these stores with more standard sizes of windows (storm windows typically must be ordered and customized to fit the size and style of the primary window). Larson has indicated that it has begun to see more significant growth in sales in areas where stock windows are available for purchase in big-box home improvement stores. A recent, noticeable increase in sales of low-e storm windows in Pennsylvania has been driven primarily by DOE-supported projects including the integration of low-e storm windows as a qualified measure in Pennsylvania’s low-income WAP (see text box on Pennsylvania Weatherization Experience).

Low-e storm windows are sold and installed in all climate zones throughout the United States. Figure 3.1 provides the percentage split for the national distribution of storm window sales. As shown in Figure 3.1, sales are more concentrated in the relatively cooler climates of the northern Midwest and northeastern states; however, the warmer southeastern states make up over $25 \%$ of sales. The northwestern states have the lowest sales.

\footnotetext{
${ }^{9}$ Estimate based on AAMA estimates as reported in 2009 Energy Data Book (EIA). AAMA estimates provided for 1990-2005 and trended downward based on industry input and information as well as the overall economic and construction trends during this period.
} 


\section{Storm Window Sales Estimated by U.S. Census Division}

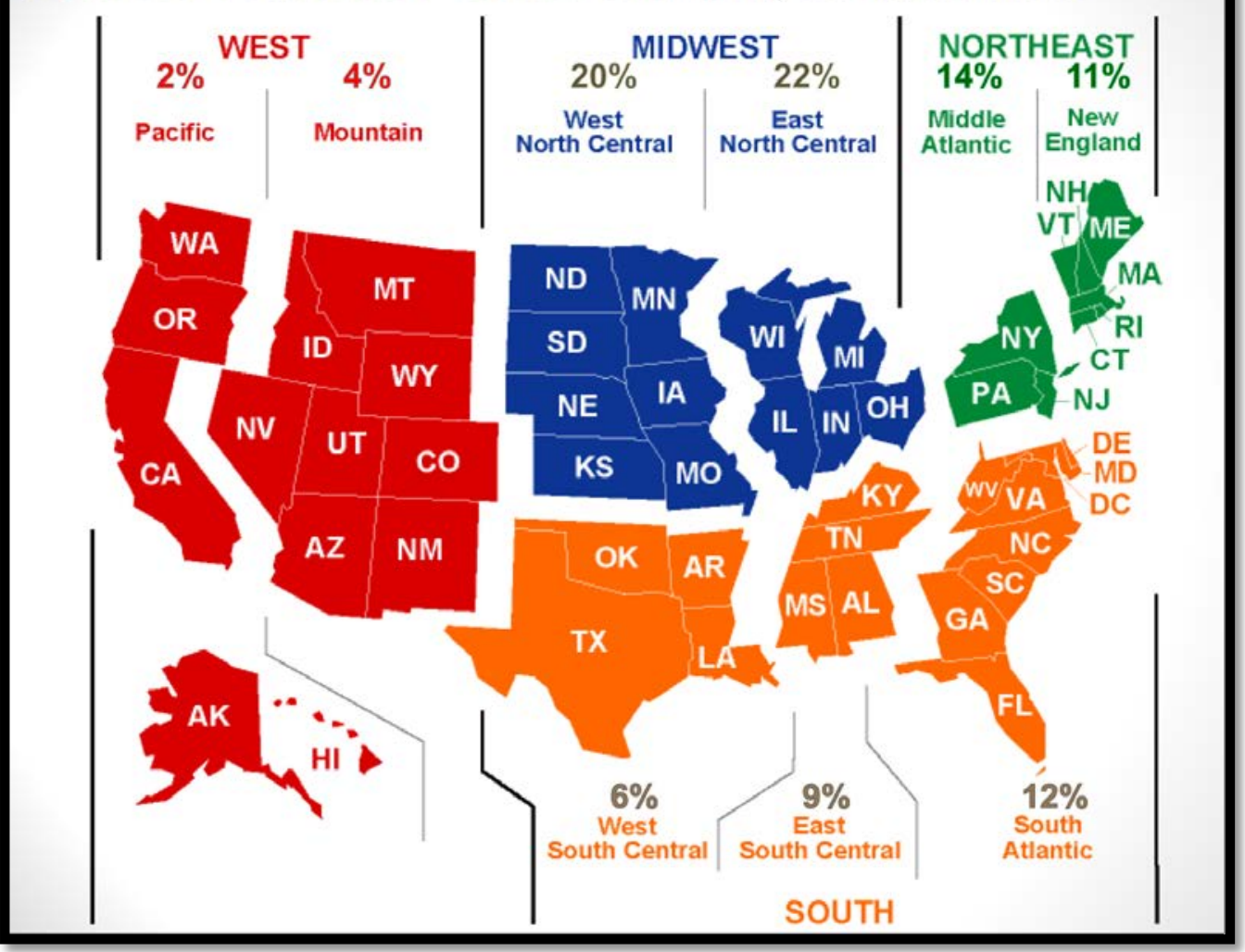

Figure 3.1. Percentage of National Storm Window Sales (2012) estimated by the U.S. Census Division $\left(\right.$ USBC 2012) ${ }^{10}$

\subsection{Target Market}

In terms of energy savings, the homes and buildings that realize the greatest benefits from the installation of low-e storm windows are those with single-pane, low-performing, leaky windows. DOE's 2009 Residential Energy Consumption Survey (RECS) estimated that approximately 47.2 million (or $\sim 40 \%$ ) of existing residential homes have single-pane windows (DOE-EIA 2009). Although some of these may have storm windows attached, the vast majority would be older storm windows with higher air leakage and without high-performing low-e glass. Based on preliminary data from the 2013 PNNL Lab Homes study conducted by Pacific Northwest National Laboratory, residential homes with double-pane clear windows (i.e., no low-e coating) would also realize significant energy savings benefits from the installation of low-e storm windows. Based on RECS data and replacement window shipment data, approximately 46 million homes have windows with double-pane clear glass (AAMA 2012). ${ }^{11}$

\footnotetext{
${ }^{10}$ Regional splits for storm window sales provided by Larson Manufacturing, 2012.

${ }^{11}$ Although the 2009 RECS did not include estimates of double-pane clear windows, the 2005 RECS survey estimated 50.6 million homes with double-pane clear windows (DOE-EIA 2005). The current estimate is based on estimates of prime window replacements (AAMA 2012) during the timeframe and window trends between the 2005 and 2009 RECS.
} 


\subsection{Climate Zones}

Although the field testing and early target market for low-e storm windows has been directed toward the colder, more heating-dominated northern states, as shown in Table 3.1, the installation of a low-e storm window also reduces the solar heat gain coefficient, which provides a cooling benefit by reducing radiant heat gains. Quanta Technology offers low-e storm windows with both high and low solar heat gain coefficients to accommodate both cooling- and heating-dominated regions and has had success with sales in both climate zones. Further, low-e storm windows reduce infiltration, which can be a significant source of heat gain in the cooling season and storm windows appear to be as readily sold in some of the warmer climates (e.g., the hot and humid southeastern states) as some of the cooler states (see Figure 3.1 and Figure 3.2). Thus, the potential target market for this technology could include the 93 million U.S. homes with single-pane windows and double-pane windows without low-e coatings.

Figure 3.2 breaks out the number of households with single-pane and double-pane clear windows by Census region. Each region has a similar number of existing homes with either single-pane or doublepane clear windows (ranging from 17-20 million per region). The sales for storm windows, however, are more concentrated in the Midwest ( $42 \%$ of sales), while the West only accounts for $6 \%$ of storm window sales, despite having an estimated 20 million homes with single-pane or double-pane clear windows. Although some of the more populous regions of the West, such as the coastal portion of California or central Arizona, have very mild climates, several mountainous states in the West and the northwestern coastal region have extensive heating seasons.

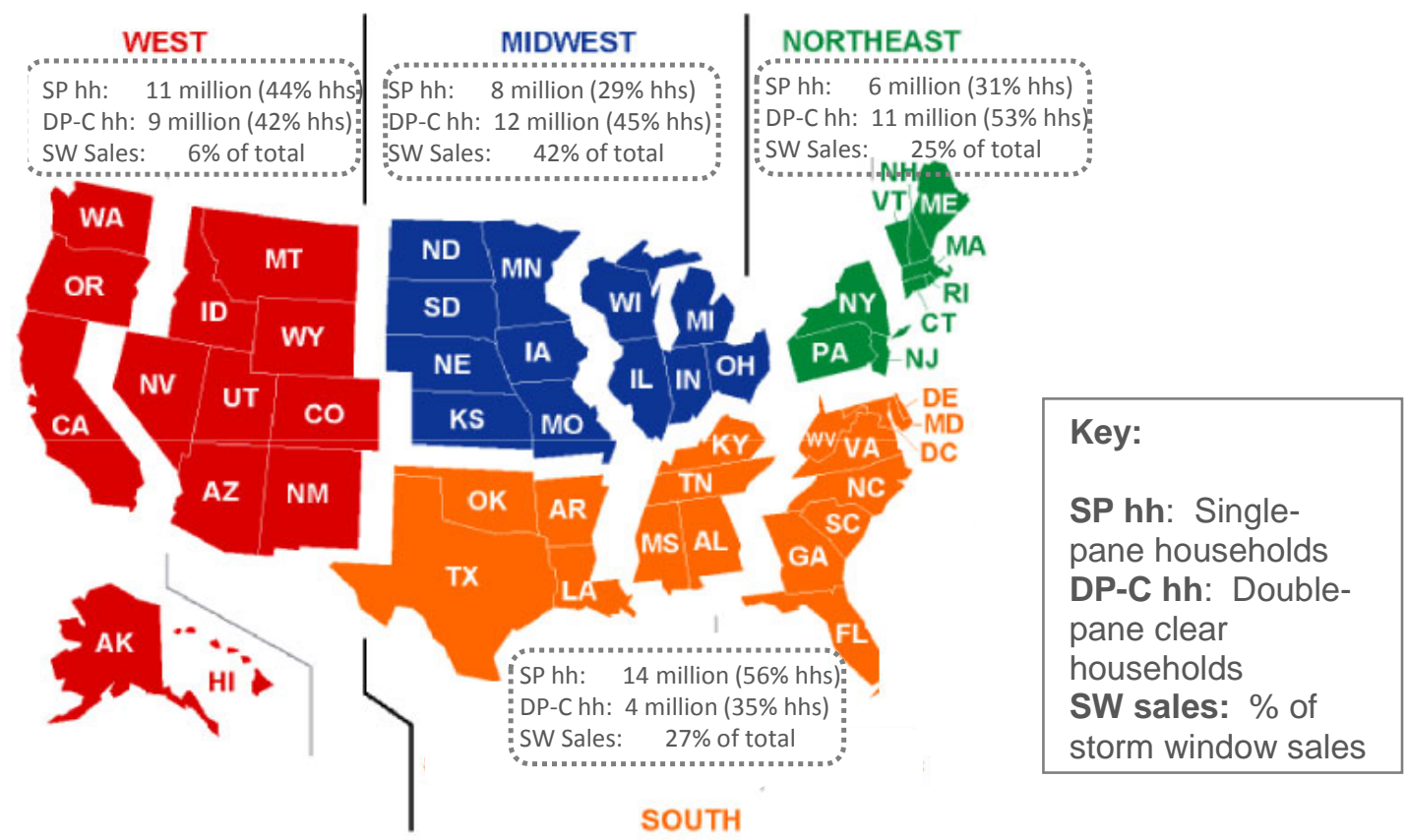

Figure 3.2. Number of households with single-pane and double-pane clear by U.S. Census Division. Percentage of total storm window sales (2012) estimated by Census Division ${ }^{12}$

\footnotetext{
${ }^{12}$ Regional splits for storm window sales provided by Larson Manufacturing, 2012. All other estimates based on RECS 2005, RECS 2009, calibrated with AAMA 2012 replacement window sales estimates.
} 


\subsection{Demographics and Customs}

Storm window installations do not appear to be tied to a single demographic; however, the affordable nature of this retrofit measure makes it a candidate for lower, middle-income households and lower-cost rental homes. Some regional customs may drive the installation of storm windows, which may explain why storm windows are more typical in some regions and relatively rare in others despite the energy and comfort advantages of having storm windows in place. Although higher-end, expensive homes may not seem to be potential customers for this lower-cost measure, consideration of this energy-efficiency measure may depend more on the homeowner's preference and the type of house than on income level. High-end homeowners in historic districts, for example, may choose to install storm windows to improve comfort while maintaining the look of their wood-framed windows. Quanta Technologies noted that they have had success in this area installing low-e windows in historic residential and commercial buildings in Pennsylvania, Virginia, and Georgia.

\section{Non-Residential Applications}

Traditionally, residential homes have made up the market for storm windows; however, some commercial applications could be considered. Low-e storm windows could be an appropriate retrofit measure for small commercial buildings with poorly performing windows, historic buildings, and commercial buildings that house residents (e.g., nursing homes, hotels and motels, and dormitories). Preliminary findings from the DOE-funded multifamily case study in Philadelphia demonstrated energy benefits using Quanta Technologies' interior low-e storm windows for large apartment buildings (Quanta Technologies 2013). For larger building applications where the windows are similar size throughout, mass application of interior low-e storm windows can be a cost-effective option for reducing HVAC loads.

Based on DOE's Commercial Buildings Energy Consumption Survey (CBECS), there are just over 2 million occupied, small, (i.e., 5,000 $\mathrm{ft}^{2}$ or less) commercial buildings (not including vacant buildings or warehouses) and approximately 50\% of these buildings have single-pane glass windows. In addition, over 140,000 commercial buildings house overnight residents. Approximately $35 \%$ of these buildings have single-pane glass windows (CBECS 2003).

\subsection{Marketability}

In addition to the energy-saving benefits documented in Table 2.1, low-e storm windows have marketable benefits such as added comfort and noise reduction. Further, window attachments protect primary windows and the extra pane of glass could be considered a security measure.

The visual framing and style of storm windows varies. For the most part, the style can be customized to match the style of the primary window. For example, a double-hung, white, vinyl-framed primary window would be could be matched with an operable, double-hung, white-framed storm window. Thus, the modern-day exterior or interior storm window attachment could have neutral visual impact on the primary window if that is what is desired. In many situations, however, the aesthetics of a home's façade can be improved with the application of storm windows, particularly if the primary window is unappealing (e.g., worn window frames). Participants of the Atlanta Case Study listed improved aesthetics and comfort as the most valued benefits of the storm window applications. From a 
marketability standpoint, aesthetic appeal is critical for such an architecturally important, visible retrofit measure (Quanta Technologies 2013; Hefty and Cort 2013).

Another very important feature from a marketability standpoint of any retrofit measure is the upfront cost. Because the benefits of retrofitting a window with an attachment are realized over time, these benefits are discounted in terms of their present-day importance. Despite the fact that residential consumers may live in their homes for many years, a number of surveys focusing on energy-efficiency retrofits in homes have found that most people require paybacks of 3 years or less to invest in a product and some will even require paybacks of 1 year or less (McKinsey \& Company 2011). Surveys focusing on commercial building owners and managers also identified a 3-year payback on energy-efficiency investments as the most frequent "acceptable payback period" by respondents; however, in a Johnson Control study, ${ }^{13}$ approximately $40 \%$ of the respondents indicated that they would tolerate up to a 10 -year payback period for longer-lasting envelope measures (Johnson Controls 2010). Other metrics besides simple payback are sometimes used, including internal rate of return (IRR) and savings-to-investment ratio (SIR). In general, however, to penetrate a significant portion of the market, energy-efficient technologies must yield a relatively quick return on the investment.

The payback for low-e storm window installations can range from 3 to 11 years depending on climate, fuel prices, and the condition of the existing window and home. The upfront capital costs range from around $\$ 70$ to $\$ 150$ per window, which is approximately one-third of the cost of a replacement window. Installation can occur with no upfront monetary costs as a do-it-yourself project or be contracted out to a professional for approximately $\$ 60$ per window. For comparison, window replacements are rarely done as do-it-yourself projects and professional installation ranges from around $\$ 100$ to $\$ 500$ per window installation, due to the added complexity of removal and disposal of the old unit (including any necessary lead-paint practices in older homes) and installation of the new unit. ${ }^{14}$ Though the window industry has made many advances in energy efficiency over the last decade, its success has largely been limited to new housing and major remodeling projects. The cost of replacing a window prevents window replacement from being a standard energy-efficiency upgrade and the payback on investment is much too long for most homeowners to justify the expense. As a result, the vast majority of existing buildings still have inefficient windows. Further, the expense of window replacement precludes it from being considered in many energy-efficiency programs that promote cost-effective energy retrofits. For example, most weatherization programs will only fund energy-efficient weatherization measures if they meet certain cost-effectiveness criteria. This cost-effectiveness criterion is typically defined in terms of the savings-to-investment ratio (SIR), where installation of the energy-efficiency measure must yield an SIR greater than 1 to qualify for weatherization funding. While calculations of SIR values for low-e storm windows have exceeded this weatherization requirement (e.g., SIR calculations of 1.3 to 3.2 in central and northern climates), window replacements are rarely able to meet these cost-effectiveness requirements of $\operatorname{SIR}>1$.

\footnotetext{
${ }^{13}$ Johnson Controls conducts an annual survey of commercial building decision-makers. The survey referenced includes 1,400 decision-makers across North America responsible for managing commercial buildings and their energy use.

${ }^{14}$ Cost estimated from informal survey of contractors participating in energy-efficient upgrades and working groups with the CEE (Hefty and Cort 2013).
} 


\subsection{Energy Consumption and Savings Potential}

Based on RECS and the Energy Information Administration's (EIA's) Annual Energy Outlook (AEO), the energy consumed to heat and cool 93 million homes in the regions identified in Figure 3.2 would total about 4.3 quadrillion Btus annually (delivered/site energy). Based on HVAC savings ranges of 12 to 33\%, estimated using the RESFEN model in 30 cities across 7 climate zones (Zalis, et. al. 2010), a wholesale application installation of low-e storm windows in these 93 million homes would yield a technical potential energy savings ranging from 0.5 to 1.4 quadrillion Btus of delivered energy. This equals approximately 5 to $13 \%$ of total current energy consumption (delivered) in the residential sector.

Table 3.1 lists the buildings identified as potential targeted markets in the commercial sector and corresponding energy use intensities (EUIs) and consumption based on CBECS and current AEO energy consumption information. The total energy consumed to heat and cool the selected commercial buildings with single-pane windows is estimated to be approximately 170 trillion Btus annually.

Table 3.1. Targeted commercial buildings

\begin{tabular}{lcccc}
\hline \multicolumn{1}{c}{ Building Type } & $\begin{array}{c}\text { Delivered EUI } \\
\text { Heating } \\
\text { (thousand Btu/ft }{ }^{2} \text { ) }\end{array}$ & $\begin{array}{c}\text { Total Square Feet with } \\
\text { Delivered EUI Cooling } \\
\text { (thousand Btu per } \mathrm{ft}^{2} \text { ) }\end{array}$ & $\begin{array}{c}\text { Delivered HVAC } \\
\text { single-pane windows } \\
\text { (millions of } \mathrm{ft}^{2} \text { ) }\end{array}$ & $\begin{array}{c}\text { Consumption } \\
\text { (trillion Btus) }\end{array}$ \\
\hline $\begin{array}{l}\text { Small (under } \\
5,000 \mathrm{ft}^{2} \text { ) buildings }\end{array}$ & 34.8 & 7.9 & 2,840 & 121.19 \\
$\begin{array}{l}\text { Dormitories } \\
\text { Nursing homes/ }\end{array}$ & 35.3 & 2.5 & 128 & 4.85 \\
$\begin{array}{l}\text { assisted care } \\
\text { Lodging }\end{array}$ & 35.6 & 7.7 & 325 & 14.04 \\
Total & 16.7 & 4.5 & 1,307 & 27.7 \\
\hline
\end{tabular}




\subsection{Market Transformation Opportunities}

The building research conducted by the Building America program is based on the use of collaborative, industry-based teams that integrate across supply chains, business practices, and stakeholders to deliver products of value and minimize overall costs and risks. The overall goal of market transformation is to increase the share of energy-efficient products and services within targeted markets. Market transformation efforts also must recognize the importance of working with key market playersmanufacturers, distributors, retailers, and consumers-for any type of intervention. To identify and characterize market transformation opportunities and activities for low-e storm windows, this market assessment report follows the distribution "supply chain” identified by Building America for Building America research and deployment efforts related to low-e storm windows (see Figure 4.1). Figure 4.1 illustrates the high level elements of the supply chain, where more detailed components will be identified in later sections of this market assessment report.

As previously discussed in Section 3.1 and as identified in Figure 4.1, the targeted end-use customers of any low-e storm window research would include residential homeowners and occupants in homes with low-performing windows. This would include all forms of residential buildings (i.e., single-family, multifamily, and manufactured housing) at all income levels. The end customers may also include some commercial building owners and tenants, although considering Building America's residential focus, these end customers may be better reached with DOE’s Commercial Buildings Integration team.
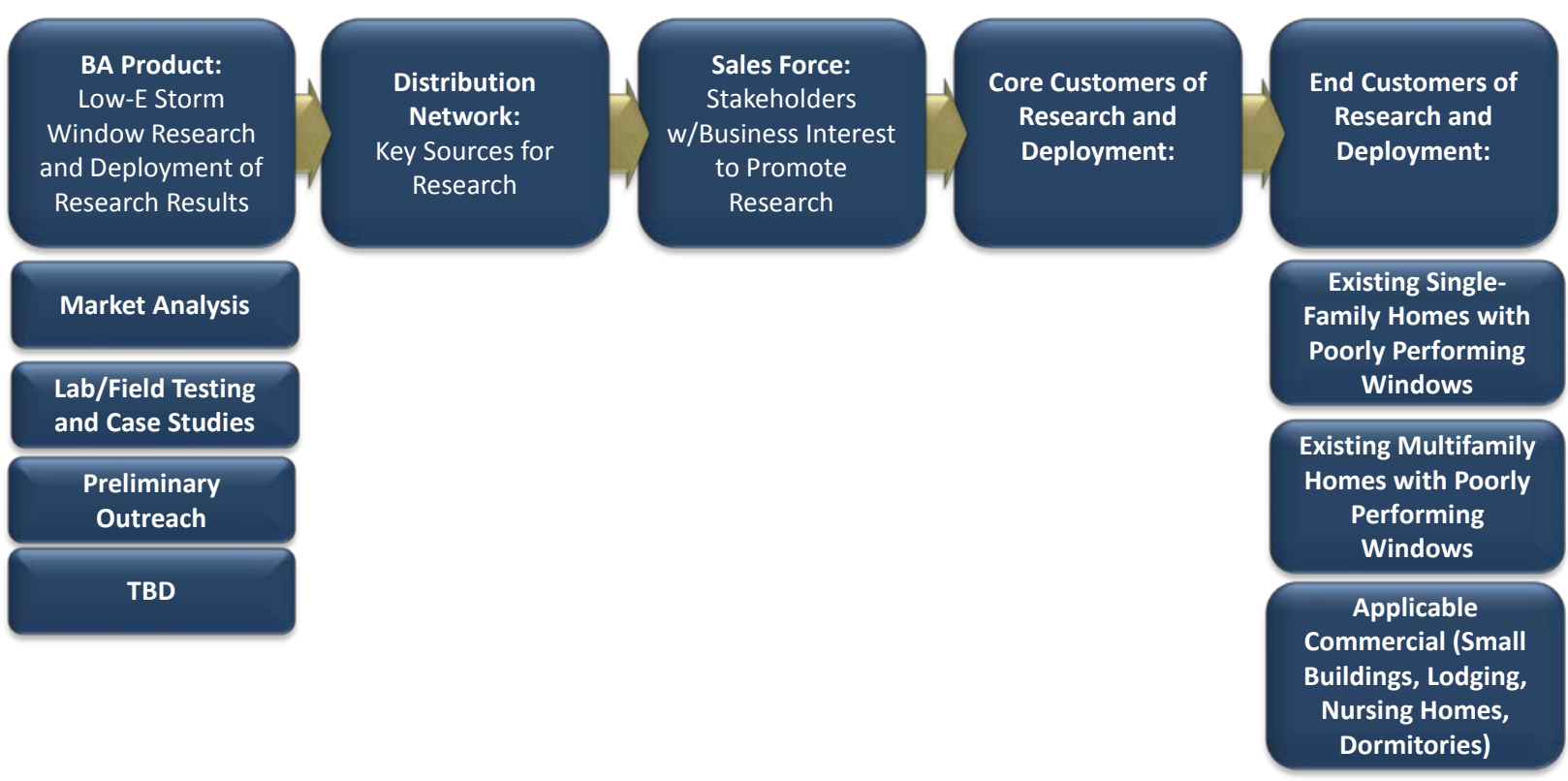

Figure 4.1. Supply chain for Building America’s low-e storm windows research and deployment 


\subsection{Home Performance Upgrades}

An estimated 8 million storm window units are sold each year. Assuming approximately 15 windows ${ }^{15}$ per home, 8 million storm window units would cover the windows of approximately 533,000 single-family homes. Currently, only a small fraction ${ }^{16}$ of these sales are low-e storm windows; however, low-e storm window sales have been growing as a fraction of total sales since becoming commercially available in 2009. It is unclear whether these storm window sales are associated with any particular energy-efficiency incentive programs; however, a search of the Database of State Incentives for Renewables and Efficiency (DSIRE) ${ }^{17}$ suggests that 18 states have at least 26 utility-sponsored incentive programs between them that explicitly identify storm windows as qualified measures. Thus, it is likely that some of these storm window sales are at least partially funded by utility-sponsored energy-efficiency programs.

Additional energy-efficiency programs could also influence the sale of storm windows, such as Home Performance with ENERGY STAR (HPwES), which is a federally supported residential energyefficiency program focusing on upgrading the existing housing stock with energy-efficiency measures. Considering the current regional distribution of existing storm window sales and the do-it-yourself nature of installations, combined with the somewhat limited nature of efficiency programs focusing on window attachments, it seems likely that most of the existing storm window sales are simply part of the estimated $\$ 12$ billion spent on home improvements related to windows and doors in each year (approximately 15\% of which includes do-it-yourself projects) (JCHS 2013).

Market Segment: In general, the specific market segment involved in energy-performance upgrades includes single-family homes that are typically middle to higher income households (i.e., not low income). This segment also includes multifamily homes (other than HUD subsidized multi-family housing).

Pathways to Market Segment: A number of paths could be pursued to tap the mainstream home performance industry, which would eventually lead to privately owned homes (whether owners of rental stock or homeowner-occupied housing). These would include reaching out to the following groups and programs:

- Retailers (big-box and independent dealers): Most storm windows are purchased by individuals from either big-box retailers or independent dealers. Considering that $80 \%$ of storm window installations are do-it-yourself projects, regardless of whether the action is incentivized by a program, the contact to the end customer comes through the retailer.

- Utility Incentive Programs: At least 18 states have utility programs that explicitly identify storm windows as energy-efficiency measures that qualify to receive rebates or forms of incentives from the utilities or state programs. Although it is not clear what impact of these programs have had on storm window sales, this clearly is a pathway that could be pursued to reach end customers. Furthermore, these programs only address storm windows in a generic sense, and do not specifically require low-e storm windows. Therefore, there is the potential to modify current programs to require or incentivize low-e storm windows and capture higher energy performance benefits. The incentive could be

\footnotetext{
${ }^{15}$ Based on “Characteristics of a Typical Single-Family Home,” from 2011 Building Energy Databook , Table 2.2.7 (DOE 2011)

${ }^{16}$ Estimated to be less than $10 \%$ in 2011 from informal industry estimate. This number has been growing. No current estimate is available.

${ }^{17}$ DSIRE database search available online at: http://www.dsireusa.org/.
} 
structured to offset any incremental cost of low-e storm windows compared to standard clear glass storm windows, to ensure that when a consumer purchases a storm window, it is a low-e storm window. This is also a pathway with great potential for growth to establish programs in the 32 states that do not include programs explicitly directed toward storm windows.

- Energy-Efficiency Retrofit and Weatherization Programs: In addition to utility-sponsored incentive programs, a number of federally sponsored programs promote energy-efficiency in existing buildings and weatherization measures. In particular, Home Performance with ENERGY STAR (HPwES) is focused on improving the energy efficiency of existing homes by facilitating whole house energy assessments through a network of qualified contractors. HPwES is a national program administered by DOE and the U.S. Environmental Protection Agency (EPA) and managed at the state or regional level. Although this program focuses on whole house retrofits, it also includes a prescriptive approach, which lists eligible measures. Inclusion in the list of eligible measures could be beneficial for the market adoption of low-e storm windows. In a 2012 survey of 7 home performance contractors that worked with HPwES, when asked to categorize the types of home performance measures, the contractors did not list the installation of storm windows in any of projects completed in a 3-year timeframe, despite the fact that a majority of the projects included air sealing and insulation activities (contractors noted that over 2000 projects were completed during the timeframe) (PNNL 2012).

There are other programs promote weatherization measures in existing homes. The largest weatherization program is DOE's WAP, which provides technical assistance and formula grants to state and local weatherization agencies and includes a network of approximately 970 local agencies, which provide trained crews to perform weatherization services for eligible low-income households in single-family homes, multifamily dwellings, and mobile homes. These programs assist market transformation not only in the retrofits directly carried out as part of the programs, but also through their training and networking with regional home performance and weatherization contractors.

- Standards and Energy-Efficiency Rating Organizations: Standards and energy-efficiency ratings can drive the market for energy-efficient products. One storm window manufacturer noted that the most frequently asked question about low-e storm windows was whether or not they had an Energy Star label. Consumers have come to rely on this label to inform their decision-making for energyefficiency products. The absence of a label may make them question performance in terms of energyefficiency. Likewise, there is not yet a U-factor or R-value rating from the Fenestration Rating Council (NFRC) or similar organization that is directed toward storm windows, which may also leave retailers and consumers to question whether low-e storm windows are worthwhile investments. The Home Energy Score is a relatively new rating system developed by DOE’s BTO, which assigns a score to an existing home, similar to a vehicle's mile-per-gallon rating. The Home Energy Score allows homeowners to compare the energy performance of their homes to other homes nationwide. It also provides homeowners with suggestions for improving their homes' efficiency. Currently, the Home Energy Score does not take into account the influence of storm windows on energy consumption and its scoring system it does not include storm windows in its list of suggested energyefficiency improvements.

\subsection{Low-Income Homeowners/Renters}

Approximately 25\% of existing residential households are at or below 150\% of the poverty level (referred to in this report as low-income). Approximately 44\% of low-income households are owner-occupied. 
Low-income households typically spend $17 \%$ of their total annual income on energy costs, compared with $4 \%$ for other households (USCB 2012). Although these homes are often in need of energy-efficiency upgrades that could reduce their energy bills, the occupants are often not able to afford the upfront costs needed to implement upgrades. ${ }^{18}$

To address the weatherization retrofit needs of lower income households, DOE's WAP administers grants by providing technical assistance and formula grants to state and local weatherization agencies. DOE leverages funding for activities conducted under WAP with contributions from the Low-Income Home Energy Assistance Program (LIHEAP) at the U.S. Department of Health and Human Services, energy utilities, state agencies, private companies, and Petroleum Violation Escrow funds. These contributions can take the form of direct project-targeted funding or in-kind contributions (e.g., staff, research-in-kind, facilities, or other nonmonetary resources).

Because of their affordability and energy savings, low-e storm windows are well-suited to meet the needs of weatherization and WAP requirements. Federally funded WAPs typically have a rather rigid list of weatherization measures that qualify as part of their program based on a savings-to-investment ratio greater than 1 . Window replacement is not a qualifying option in most all cases simply because of the high first cost involved with replacement. However, in most cases, low-e storm windows can achieve this higher savings-to-investment ratio, which makes the weatherization program a good potential avenue for market transformation. Initial calculations using the National Energy Audit Tool (NEAT) show SIR values ranging from 1.3 to 3.2 in central and northern climates, which is well qualified (Zalis et. al. 2011). In south-central zones, qualifying SIR values can also be achieved by using appropriate glass that provides solar control.

Market Segment: The market includes households eligible for federal assistance. Households categorized as eligible for federal assistance have a household income below the federal maximum standard of $150 \%$ of the poverty line or $60 \%$ of the statewide median income, whichever is higher. Individual states can set their standard at a lower level than the federal maximum. Approximately 30 million eligible low-income homes qualify for weatherization assistance.

Pathway to Market Segment: Two primary programs could serve as pathways to address the window retrofit needs of low-income households. These include WAP and HUD.

- Weatherization Assistance Program: Regional weatherization administrators accepting grant money from WAP develop their own set of criteria and weatherization measures, suited to their climates. Since its inception, WAP has assisted in the weatherization of approximately 6.4 million low-income households. As part of the 2009 American Recovery and Reinvestment Act, WAP received a significant infusion of funding to weatherize low-income homes. Nearly 790,000 homes were weatherized with this funding. As part of its low-e storm window adoption program, DOE has funded projects that examine low-e storm windows cost and performance in terms of the weatherization cost-effectiveness and modeling criteria (see text box - Pennsylvania Weatherization Experience). Low-e storm windows appear to meet the criteria. The market adoption of low-e storm windows increased in Pennsylvania when low-e storm windows were integrated into the priority list.

\footnotetext{
${ }^{18}$ From Weatherization and Intergovernmental Program website and factsheet: http://www1.eere.energy.gov/wip/pdfs/wap_factsheet.pdf.
} 


\section{Pennsylvania Weatherization Experience}

DOE's WAP provides funding and technical assistance to state weatherization agencies to assist qualifying low-income households in implementing weatherization and energy-efficiency measures. The state of Pennsylvania's WAP is administered through its Department of Community \& Economic Development, which provides onsite energy audits in low-income homes, identifies the most cost-effective energy-saving measures to be installed, and then provides installation assistance with qualified weatherization contractors. Like many states, Pennsylvania's WAP has developed a list of priority measures that meet its criteria for cost-effectively saving energy. Prior to 2010, this list did not include low-e storm windows. With the assistance of DOE, Pennsylvania's WAP conducted a series of NEAT analyses to assess the costs and benefits of integrating low-e storm windows into 37 model homes in Pennsylvania, which demonstrated a savings-to-investment ratio from 1.4 to 2.2 for low-e storm window installations. These results demonstrated that low-e storm windows exceeded the WAP minimum criteria for inclusion as a priority weatherization measure, which eventually led to a revision in Pennsylvania's WAP Field Guidance (Krigger and Van der Meer 2011) to include low-e storm windows as a priority measure addressing building shell retrofits.

The inclusion of low-e storm windows in Pennsylvania's WAP priority list occurred simultaneously to a large infusion of funds into the program from the American Recovery and Reinvestment Act of 2009 (ARRA). In the state of Pennsylvania alone, over 36,000 homes were weatherized from January 2009 to November 2011. Although the number of low-e storm window installations specifically related to the weatherization program was not tracked, information from two of the primary storm window manufacturers (Larson Manufacturing and Quanta Technologies) supplying low-e storm windows in Pennsylvania during this time period, suggests that the inclusion of low-e storm windows on the WAP priority list had a significant impact on the market adoption of low-e storm windows in Pennsylvania.

Prior to late 2010, Quanta Technologies did not manufacture storm windows, but had experience with low-e coatings for windows. With the encouragement of DOE, Quanta Technologies began manufacturing low-e storm windows with pyrolitic hard coatings, simultaneous to the revision in Pennsylvania's WAP guidance. Quanta Technologies does not produce clear (i.e., not low-e) storm windows and distributes its Quanta Panel Insulating Glass System (i.e., low-e storm window) regionally through independent dealers and selected qualified weatherization installers. Quanta Technologies low-e storm panels can also be ordered factorydirect. Because Quanta Technologies, a Pennsylvania-based company, was actively engaged in Pennsylvania's WAP, and introduced its low-e storm panel during a large budget increase to Pennsylvania's WAP simultaneous to the inclusion of low-e storm windows in its priority list, over 75\% of Quanta Technologies' low-e storm panel sales in 2011 were directly attributable to Pennsylvania's WAP. Since that time, WAP budgets throughout the country have sharply declined and Quanta Technologies has broadened its market to also offer low-e storm windows to consumers beyond just state weatherization programs. Currently only $10 \%$ of Quanta Technologies' sales are attributable to Pennsylvania's WAP program despite substantial growth in sales over the past 2 years. 


\section{Pennsylvania Weatherization Experience (continued)}

Larson Manufacturing is a South Dakota-based company with over 50 years of experience manufacturing and distributing storm windows and storm doors. Larson Manufacturing is a storm window manufacturer with nationwide distribution networks. It does not manufacture prime windows, and although its storm windows are available both with clear glass and as low-e, Larson Manufacturing's low-e storm window sales make up a growing portion of the company's overall storm window sales. With regard to the Pennsylvania WAP's impact on sales, Larson Manufacturing indicated that growth in low-e storm window sales throughout the country increased substantially (100\% increase) during the past 2 years; however, growth in Pennsylvania was notably higher (over 300\% increase). Larson Manufacturing attributes most of the Pennsylvania growth in sales to increased WAP funding and the inclusion of low-e storm windows in the WAP priority list. In general, most of Larson Manufacturing's sales are through big-box retailers and an estimated $80 \%$ of installations are carried out as do-it-yourself projects. However, installations related to Pennsylvania's WAP program were all performed by qualified weatherization installers, many of whom also purchase through big-box retailers or dealers.

Both Quanta Technologies and Larson Manufacturing participated in training efforts directed toward qualified weatherization contractors/installers in Pennsylvania. As part of the ARRA funding, Pennsylvania established its own Weatherization Training Center, which included low-e storm windows in its curriculum. In addition to individual state-specific training, DOE and its industry partners organized low-e storm window seminars for the 2011 DOE National Weatherization Training Conference, attended by over 3000 weatherization personnel. The project team hosted a large display booth including thermal performance demonstrations and hands-on installation training, which was attended by weatherization personnel from 37 different states and provinces.

Since introducing low-e storm windows to its priority list, at least two new manufacturing companies started offering low-e storm windows to the Pennsylvania area and a number of independent dealers who had not dealt with storm windows prior to 2011 began distributing low-e storm windows. Although there may have been other factors involved with this industry expansion, it would seem that Pennsylvania's inclusion of low-e storm windows in its priority list played a role in this expansion.

Although ARRA once provided substantial WAP funding, WAP is now funded solely by its regular annual budget, which has significantly contracted since 2010. Nevertheless, the following conclusions can be drawn regarding the impact of Pennsylvania's WAP on transforming the market for low-e storm windows:

1. The integration of low-e storm windows as a priority measure in WAPs can have a measurable impact on low-e storm window sales.

2. WAPs are affiliated with a network of contractors. Integrating low-e storm windows into WAPs helps develop a sales force for technology deployment-educating and training a group of installers and contractors in a given region.

3. Introducing low-e storm windows into the Pennsylvania WAP increased their overall availability in the market. 
- Housing and Urban Development: HUD oversees 1.12 million federally owned public housing units, locally administered by about 3,100 public housing agencies. Public housing serves lowincome households - $40 \%$ are extremely low-income, with incomes no greater than $30 \%$ of the local median incomes. Although many of the HUD houses are in need of energy-efficiency upgrades, weatherization, and repairs, very limited funding is allocated to address these needs. In 2009 HUD and DOE signed a Memorandum of Understanding (MOU) promising greater cooperation in weatherizing the multifamily housing stock. To that end, a revised set of guidelines was issued by DOE that makes it easier to weatherize HUD housing by assuming that certain HUD units would be deemed qualified for weatherization.

- Possible Alternative Pathway (non-Federal): As budgets for weatherization assistance are reduced, it may be worthwhile to consider other, non-profit organizations that focus on home improvements for low-income households (e.g., Rebuilding Together, Habitat for Humanity, Enterprise Community Partners, and local initiatives). Organizations that focus on elder/senior care might also be appropriate considering that $44 \%$ of elderly (65 and older) households are classified as $200 \%$ of poverty level or less (USBC 2012).

\subsection{Federal Buildings}

Although the vast majority of residential building stock is privately owned, a portion is owned by the government. Federally owned residential stock primarily includes military housing and barracks. In an effort to reduce energy consumption in the federal sector, which is the nation's single largest energy consumer, a number of laws and executive orders have been enacted over the years to establish requirements and direct the reduction of energy and water consumption in federal facilities. The Energy Policy Act of 2005 (EPAct 2005) and Title IV, Subtitle C of the Energy Independence and Security Act of 2007 (EISA) provide the legislative foundation for other guidance and executive orders that set goals for energy-efficiency improvements in federal facilities.

Market Segment: Applicable federally owned buildings: military housing, army barracks, dormitories, and Veterans Administration patient facilities.

Pathway to Market Segment: Although the U.S. Department of Defense (DoD) and Government Services Administration (GSA) are the largest "landlords" of federally-owned residential buildings, building energy management activities are coordinated through DOE’s Federal Energy Management Program:

- FEMP: The Federal Energy Management Program (FEMP) is charged with facilitating the federal government's implementation of energy management and investment policies and assisting agencies in meeting EPACT/EISA requirements and meeting energy-saving goals. FEMP works with other agencies (e.g., GSA, DoD), who act as landlords for a substantial portion of the government building stock, to implement energy-management activities. Any active market transformation activities related to transitioning government-owned residential stock would need to work with these agencies.

- Energy Star (DOE/EPA): The Energy Star label is referenced heavily in many of the Executive Orders and guiding principles that direct energy management in the federal sector. Although Energy Star labels are used to identify the higher performance replacement windows, storm windows do not carry Energy Star labels. Market transformation activities related to low-e storm windows should address the fact that the low-e storm windows do not have an Energy Star label. 


\subsection{Commercial Buildings}

Some of the case studies related to low-e storm window (e.g., the Philadelphia Multifamily Case Study) demonstrated energy savings of low-e storm window building types more commonly found in the existing commercial building stock. For example, interior applications of storm windows could benefit commercial buildings that house residents in a similar manner such as high-rise multifamily buildings (e.g., nursing homes, assisted living facilities, and dormitories). Low-e storm windows could also be appropriate retrofit measures for small commercial buildings with poorly performing windows and historic buildings with building code restrictions that limit window replacement. Because this report is primarily focused on Building America's role in transforming the market, which is focused more on residential buildings, the commercial market segment is not thoroughly assessed or characterized.

Market Segment: Applicable commercial buildings (e.g., dormitories, nursing homes, assisted living facilities, historic institutional buildings, and small commercial buildings [under $5,000 \mathrm{ft}^{2}$ ]) could benefit from the application of low-e storm windows.

\subsection{Supply Chain for Market Transformation.}

Based on the market segments and the pathways identified for each segment, the market transformation supply chain should include utilities (i.e., sponsors of regional energy-efficiency programs), retailers and distributors of low-e storm windows, WAPs, government agencies that manage residential stock (e.g., GSA and DoD), and standards and rating organizations. On the supply chain (Figure 4.2) these would represent the Core Customers of Research and Deployment related to low-e storm windows and they act as the primary contacts with the end customers. The supply chain sales force for deployment would include stakeholders with a business interest to promote the performance and market research related to low-e storm windows (e.g., storm window manufacturers, installers and home performance contractors, and FEMP). The sales force would also include energy-efficiency consortiums (e.g., CEE), Building America teams, Better Building (BB) teams, and for commercial end customers, DOE’s Commercial Buildings Integration (CBI) teams. 


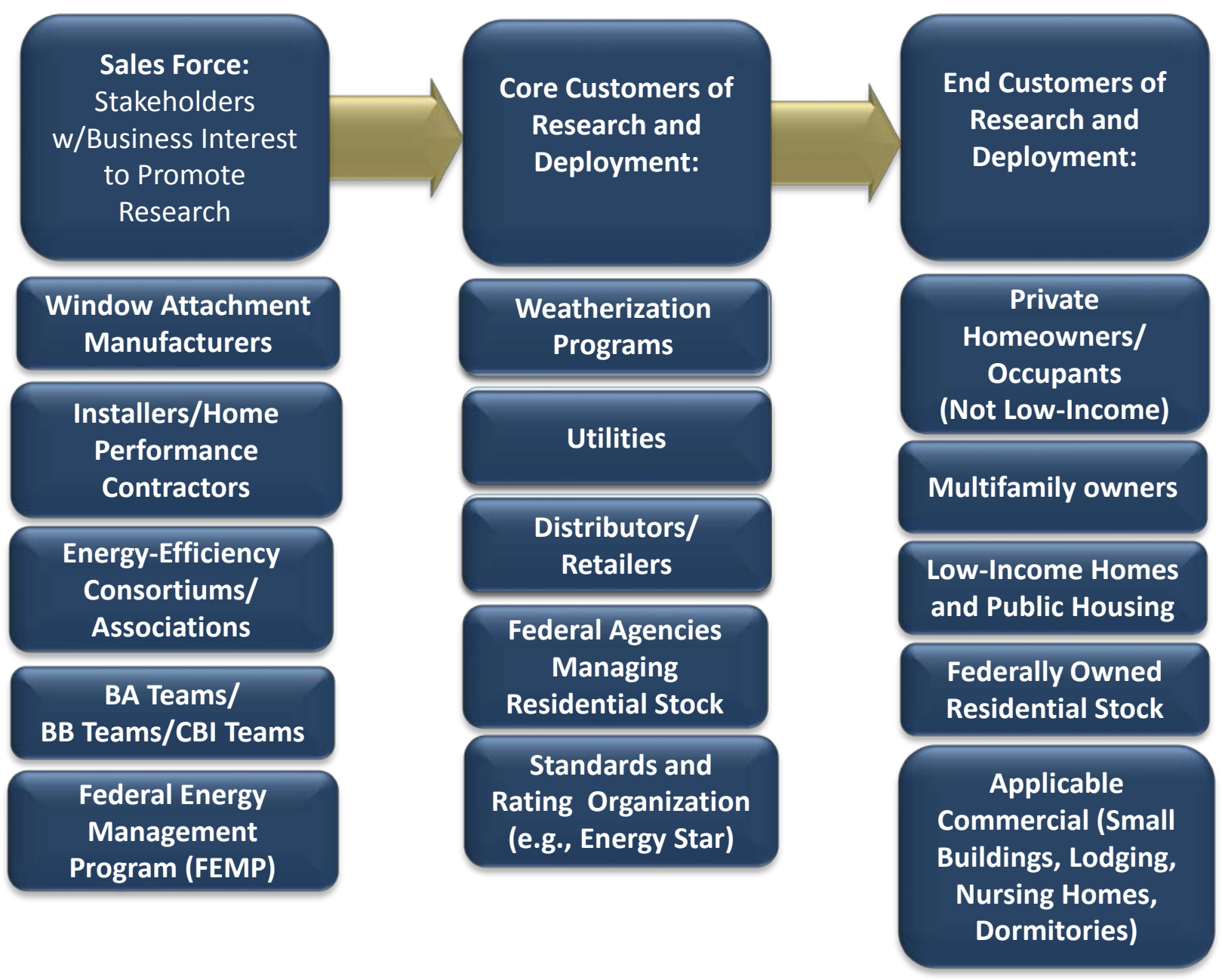

Figure 4.2. Supply chain (including contact points with end customer) 


\subsection{Barriers}

Although the cost and performance attributes of low-e storm windows set the stage for wide-scale market success, some significant barriers to deployment have been noted based on early experience in the market.

\subsection{Potential Market Barriers}

Based on market research and input from low-e storm window industry representatives and researchers who participated in low-e storm window case studies and pilot programs, the following potential barriers to market adoption have been identified:

1. Identity crisis: End-users and energy-efficiency program administrators appear to be confused regarding storm windows, low-e coatings, and their classification as an energy-efficiency measure. Storm windows seem to fall between the cracks of being windows and insulation (e.g., they have no ratings from the NFRC, which rates the performance of windows and no rating as an insulation measure). Weatherization program administrators often categorize storm window installations in the same category as window replacements. Because window replacements are usually too costly to qualify as weatherization measures, by association, storm windows are also dismissed as qualified measures. To contend with this issue of identity, some window attachment manufacturers have started to refer to storm windows as storm panels to distinguish them from prime windows and previous generations of storm windows.

2. Stigma: Storm windows suffer from an image problem due, in part, to the some of the more homely, inoperable storm windows of the past. Further, previous generations of storm windows were typically only installed during the winter and taken down for the remainder of the year, making their installation a tedious annual chore. Previous generations of storm windows were not always well sealed, became dirty easily, and built up with condensation. Despite the improvements that have been made to the sealing, framing, aesthetics and operability of storm windows, the stigma persists and potentially hampers market uptake. Storm windows may also be thought of by some as lower-class quick-fix measures to a home.

3. Not recognized by rating systems: Despite the proven energy savings of low-e storm windows, no standard rating system or energy-efficiency label exists for storm windows. As previously mentioned, NFRC provides ratings for windows, but not for storm windows. This impacts other areas, such as building energy standards and codes, federal tax energy-efficiency rebates, and various energy-efficiency programs that reference the product ratings of NFRC or other reputed organizations as criteria for meeting requirements or qualifying for funding and programs. Although Energy Star has labels for windows, there is no Energy Star label for storm windows. One industry representative mentioned that one of the most frequently asked questions by potential low-e storm window customers was whether or not the product has an Energy Star label. Consumers have come to rely on the Energy Star label to guide their decision-making process related to energy-efficient products. The absence of this label and rating potentially hamper the market uptake of this product. Likewise, although it is a newer rating system, DOE's Home Energy Score does not take into account the influence of storm window attachments on energy consumption and it does not include low-e storm windows (or any window attachments) in its list of recommended improvements. 
4. Potential code barriers: Although no specific building code barriers have been identified, this is an area to continue to watch to ensure no code barriers arise that could impede growth in certain markets. As more third-party installations occur, and if installations of storm windows occur during major renovations, code barriers may surface. Both the International Energy Conservation Code (IECC) and ASHRAE ${ }^{19} 90.1$ provide allowances for storm windows installed over existing windows, since they improve energy performance. Furthermore, the new ASHRAE 90.1-2013 requires that any storm windows include low-e coated glazing unless the existing window already includes low-e glass. However, installations of storm windows in certain hazardous locations defined by the building code require special tempered glass that adds extra cost, such as interior panels in overhead glazing or in bathrooms near a bathtub. Certain federal buildings may also have certain blast resistant requirements that require laminated glazing and special anchorage.

5. Do-it-yourself (or not): One manufacturer noted that $80 \%$ of storm window installations are do-ityourself projects. In some marketability respects this is good news, as it implies low-cost and easy installation. However, this indicates that third-party installation contractors and installers are not common and that this potential "sales force" has not been well developed. Further, many do-ityourself projects are put off for another day or simply never happen. If storm windows are fixed in the do-it-yourself category, they may fall victim to procrastination and installation of storm windows will only occur after the homeowner gets around to fixing the hole in the fence, programming the thermostat, and cleaning out the closets.

6. Industry structure: Most storm window manufacturers also manufacture prime windows. Some in the industry have noted that the profit margin on prime window replacement is greater than that for storm windows; thus, the majority of manufacturers do not have a great incentive to push storm windows. Instead they classify them as a secondary product, available on a customized basis for special orders only. Further, due to the customized nature of this product, there are a number of smaller storm window manufacturers have only regional distribution networks. There is only one storm window manufacturer with national distribution that is not also a prime window manufacturer (Larson Manufacturing Company). Most of these smaller regional manufacturers currently only manufacture clear storm windows.

\subsection{Assessment of Potential Show-Stoppers}

In addition to the potential market barriers discussed above, we've identified several concerns program managers and other stakeholders might have that could limit market adoption of storm windows. We've addressed these potential "show stoppers" in a question and answer format here.

\section{Does the installation of low-e storm windows preclude homeowners from making deeper energy retrofits in the future?}

No. Building America's overall energy goal is to demonstrate cost-effective strategies that can reduce home energy use by up to 50\%, for both new and existing homes, in all climate regions by 2017 (DOE-EERE 2013). Because this ambitious goal focuses on deep, whole house retrofits, it

\footnotetext{
${ }^{19}$ The American Society of Heating, Refrigerating and Air Conditioning Engineers (ASHRAE) is referenced in this report to represent the larger commercial building energy standard developing body referred to as ANSI/ASHRAE/IESNA, where ANSI is the American National Standards Institute and IESNA is the Illuminating Engineering Society of North America.
} 
would not be in Building America's interest to invest heavily in lighter, quick-fix energy-efficiency remedies that are not sustainable and/or hinder future, deeper retrofit strategies that are on the horizon. There is no reason to believe that low-e storm windows would hinder deeper strategies.

Although low-e storm windows can be installed as year-round, permanent installations, they can also be easily removed and reconfigured. The upfront investment is modest compared to many enclosure measures and the payback is rapid, such that long-term installations are not required to reap a return on the investment.

2. Do low-e storm windows distort viewing through prime windows or have any associated disamenities and durability issues that would limit their marketability?

No. Although some have noted that storm windows can have issues with condensation (which could potentially distort viewing) and maintenance (e.g., hard to clean), low-e window manufacturers have not experienced any complaints with either condensation or maintenance issues. Both Quanta Technologies and Larson Manufacturing Company provide long-term warranties (e.g., 20 years) on their low-e products.

3. Are there any known building code barriers that would prevent the wide-scale deployment of low-e storm windows?

None known. No specific code (fire, energy, etc.) barriers have been identified; however, this is an area that would require more extensive research to determine whether any building or energyefficiency code barriers do currently exist.

4. Is installation of low-e storm windows costly and/or complicated or prone to incorrect installation that may prevent energy savings from being achieved?

No. Although low-e storm windows must be made to fit the window, which requires accurate measurements, it is not a complicated process. The installation itself is simple enough to be completed by the homeowner as do-it-yourself projected and installation is also offered through weatherization/home energy contractors..

\section{Are low-e storm windows only applicable to new buildings?}

No. This technology is geared toward the existing, retrofit building market.

6. Would the adoption of low-e storm windows have a measurable impact in terms of energy reduction?

Yes. The performance has been validated to achieve between 12 and 33\% in HVAC savings (Zalis, et. al. 2010). Because this is an affordable measure that can be applied to millions of existing homes, the potential energy-saving impacts are significant.

7. Would wide-scale market deployment of low-e storm windows occur without government support?

Not likely. Although low-e storm windows have proven to be a successful commercial product, a number of barriers in the market could hinder wide-scale adoption. Barriers that would most 
effectively be addressed with DOE support include the lack of recognition by an appropriate rating organization, overcoming hurdles related to including low-e storm windows as a prioritized weatherization measure, and utility acceptance. In many of these cases, Building America can use its tools and technical expertise to act as an honest broker to validate performance claims and facilitate the exchange of information to accelerate market uptake of low-e storm windows.

\subsection{Summary of Barriers}

No show-stopping features - that is, features that would preclude DOE's investment in deployment activities and/or severely limit market adoption for low-e storm windows -- are readily apparent. However, several market barriers to adoption have been identified. Some of these barriers, such as industry structure and persistent stigma issues, may not be easily addressed with Building America efforts; however, other barriers could be overcome by Building America's research, outreach, education, and technical assistance programs. These barriers and potential strategies to overcome these barriers are discussed in the Section 6. 


\subsection{Strategies and Impacts}

With a successful market transformation program, low-e storm windows could have a major impact on reducing heating and cooling consumption in the residential sector.

\subsection{Market Transformation Strategies}

Although market transformation can take a number of different forms, based on the market segments and pathways to these markets characterized in Section 4 and the barriers to market adoption identified in Section 5, the following research areas, outreach, and technical assistance may serve as effective strategies to transform the market for low-e storm windows (see Table 6.1).

Table 6.1. Barriers, strategies, and pathways to market transformation for low-e storm windows

\begin{tabular}{|c|c|c|}
\hline Barriers & Strategies & Pathways “Core Customers” \\
\hline Identity crisis & $\begin{array}{l}\text { Determine and validate performance in multiple climate zones. } \\
\text { Tailor analysis and tools to WAP criteria to integrate low-e } \\
\text { storm windows and weatherization measures. Disseminate } \\
\text { information to relevant stakeholders, leveraging credibility } \\
\text { from Building America, DOE, and national laboratories. } \\
\text { Continue interactions and participation in CEE working groups } \\
\text { and outreach efforts. Follow initial contacts with utilities. }\end{array}$ & $\begin{array}{l}\text { Codes and rating } \\
\text { organizations, WAP, utilities, } \\
\text { and CEE }\end{array}$ \\
\hline Stigma & $\begin{array}{l}\text { Building America should continue in its role as an honest } \\
\text { broker of research and information. It should determine and } \\
\text { validate the performance of low-e storm windows, including } \\
\text { how different circumstances and climate regions may impact } \\
\text { this performance, tailoring modeling tools to integrate low-e } \\
\text { storm window performance. Building America should } \\
\text { effectively disseminate this information to appropriate } \\
\text { audience. }\end{array}$ & $\begin{array}{l}\text { Utilities, CEE, WAP, and } \\
\text { Federal agencies }\end{array}$ \\
\hline $\begin{array}{l}\text { Not recognized } \\
\text { by rating systems }\end{array}$ & $\begin{array}{l}\text { Continue to support and working groups focused on } \\
\text { establishing rating system for low-e storm windows. Work } \\
\text { with Energy Star and Home Energy Score teams. }\end{array}$ & $\begin{array}{l}\text { Codes and Rating } \\
\text { Organizations (NFRC, } \\
\text { Building America's CSI } \\
\text { team, Energy Star } \\
\text { (EPA/DOE), Home Energy } \\
\text { Score (DOE) }\end{array}$ \\
\hline $\begin{array}{l}\text { Potential code } \\
\text { barriers }\end{array}$ & $\begin{array}{l}\text { Utilize Building America's Codes and Standards Innovation } \\
\text { (CSI) Team to monitor code activities to ensure no code } \\
\text { barriers arise to hinder use of low-e storm windows. }\end{array}$ & Building America's CSI team \\
\hline $\begin{array}{l}\text { Do-it-yourself } \\
\text { confinement }\end{array}$ & $\begin{array}{l}\text { Develop third-party contractors through outreach, education, } \\
\text { and technical assistance efforts directed toward WAP, HPwES, } \\
\text { and FEMP deployment efforts. }\end{array}$ & WAP, HPwES, FEMP \\
\hline $\begin{array}{l}\text { Industry } \\
\text { structure }\end{array}$ & $\begin{array}{l}\text { No specific strategy identified. If the demand for low-e storm } \\
\text { windows exists, the industry will expand; thus, general } \\
\text { deployment efforts would be the best approach to address this } \\
\text { barrier. }\end{array}$ & \\
\hline
\end{tabular}




\subsection{Market Impacts}

Based on analysis of the end-use customers characterized in in Section 4 and the market transformation strategies identified in Section 6.1, the market for low-e storm windows can be divided into the following segments:

- privately owned mid- and high-income homes (single-family and multifamily)

- low-income homes

- public housing authorities/administrators

- applicable federally owned building stock (e.g., military housing, barracks, dormitories, and Veterans Administrations care facilities)

- applicable commercial buildings (e.g., dormitories, lodging, nursing homes/assisted-care facilities, and small residential-style buildings).

Different contact points and avenues could be pursued to reach each of these market segments. Table 6.2 summarizes the applicable strategies/pathways coupled with the market segment and briefly describes the size of the market. An attempt was made to determine the reasonably achievable level of market adoption in each market segment based on current and projected funding levels for assistance programs, such as WAP, as well as current levels of market adoption (e.g., current storm window sales and current levels of energy-related retrofits). Modest improvements to low-e storm window sales and retrofits were projected based on transformation activities directed toward particular sectors and programs. These assumptions are described in Table 6.2.

Based on the assumptions presented in Table 6.2, the overall size of the market for low-e storm windows that could be reached on an annual basis with the assistance of market transformation activities is estimated to be approximately 800,000 homes. ${ }^{20}$ Figure 6.1 shows a break-out of these market segments and by the programs and market transformation activities that influence them.

The bar on the left of Figure 6.2 presents the "Business as Usual” case, which assumes that storm window sales will continue as usual. The bar on the right illustrates the market penetration of low-e storm windows with an active market deployment and market transformation program. The annual sales with market transformation are assumed to be reached over a 5 to 10 -year time period. Without market transformation activities, the market would likely be limited to the blue area of the graph - traditional storm window sales, and one could argue that it would take more time to reach this goal without the influence of market transformation activities directed toward validating low-e storm window performance and assisting the identified "sales force" to effectively disseminate information.

In general, it is likely that the transformation efforts and successes in one targeted sector will influence the market in other sectors. For example, market growth in weatherization programs will help increase availability of low-e storm windows and develop contractors and installers who would then also be available for other federal/state and utility-incentive programs directed toward low-e storm windows. As more contractors and individuals order low-e storm windows through big-box retailers and independent

\footnotetext{
${ }^{20}$ To quantify commercial buildings in a similar manner to residential homes, these buildings were converted to "household equivalents" by dividing the total square footage into multifamily-sized parcels (assumed to be approximately $950 \mathrm{ft}^{2}$ ).
} 
Table 6.2. Size of market segment and potential pathways to market transformation

\begin{tabular}{|c|c|c|}
\hline Market Segment & Size of Market Segment & $\begin{array}{l}\text { “Core Customers” of Building } \\
\text { America Market Research (Pathway } \\
\text { to Market Transformation) }\end{array}$ \\
\hline $\begin{array}{l}\text { Privately owned } \\
\text { mid- and high- } \\
\text { income homes } \\
\text { (single-family } \\
\text { and } \\
\text { multifamily) }\end{array}$ & $\begin{array}{l}\text { - At a minimum, this should include customers who } \\
\text { have historically purchased storm windows, assuming } \\
\text { most of these sales (i.e., 90\%) could eventually be } \\
\text { low-e storm windows (sales assumed to continue at } 8 \\
\text { million units per year). } \\
\text { - This market could grow if more direct utility incentive } \\
\text { programs were put into place and programs such as } \\
\text { Energy Star were to include low-e Storms (On } \\
\text { average about 1-2\% of homes perform energy-related } \\
\text { retrofits. This assumes that a small portion of these } \\
\text { (10\%) would include low-e storm windows with } \\
\text { directed incentive program.) } \\
\text { - This market could grow if programs targeting } \\
\text { residential retrofits, such as HPwES and BB included } \\
\text { directed education/training and outreach efforts } \\
\text { toward low-e storm windows (HPwES retrofit 50,000 } \\
\text { homes in 2011). }\end{array}$ & $\begin{array}{l}\text { - Utilities (utility-sponsored } \\
\text { weatherization and incentive } \\
\text { programs directed toward energy- } \\
\text { efficiency of the enclosure) } \\
\text { - Standards and rating systems such } \\
\text { as Energy Star could have a } \\
\text { significant influence on the home } \\
\text { performance market by establishing } \\
\text { a program for window attachments. } \\
\text { - Distributors/retailers have the most } \\
\text { direct contact with private } \\
\text { homeowners considering home } \\
\text { performance upgrades. Outreach } \\
\text { and education (by manufacturers or } \\
\text { DOE) should be considered. }\end{array}$ \\
\hline $\begin{array}{l}\text { Low-income } \\
\text { homes }\end{array}$ & $\begin{array}{l}\text { - The size of this market is largely influenced by the } \\
\text { size and structure of WAPs directed toward lower } \\
\text { income homes, whether government-subsidized or } \\
\text { driven by utilities and non-profits (current annual } \\
\text { federal funding levels and state matching would result } \\
\text { in about 46,000 homes weatherized each year). } \\
\text { - Because this can be a do-it-yourself, generally } \\
\text { affordable measure, this market segment could also be } \\
\text { reached by general informational campaigns coming } \\
\text { from any program or retailer. }\end{array}$ & $\begin{array}{l}\text { - WAPs } \\
\text { direct contact with private } \\
\text { homeowners considering home } \\
\text { performance upgrades. Outreach } \\
\text { and education (by manufacturers or } \\
\text { DOE) should be considered. }\end{array}$ \\
\hline Public housing & $\begin{array}{l}\text { - The size of this market is directly linked with HUD } \\
\text { budgets directed toward retrofits and WAP (Based on } \\
\text { funded projects, assumed approximately 2\% of public } \\
\text { housing units could be retrofit each year). }\end{array}$ & $\begin{array}{l}\text { - WAPs } \\
\text { - HUD budgets and programs }\end{array}$ \\
\hline $\begin{array}{l}\text { Federally } \\
\text { owned } \\
\text { residential } \\
\text { buildings }\end{array}$ & $\begin{array}{l}\text { - The size of this market is linked with federal mandates } \\
\text { directed toward improving the efficiency of existing } \\
\text { federally owned building stock as well as the budgets } \\
\text { and programs used to implement these efficiency } \\
\text { retrofits. It is also influenced by standards and rating } \\
\text { programs, as the legislative requirements and } \\
\text { executive orders refer to ratings (based on goals and } \\
\text { budgets, assumed approximately 10\% of federal } \\
\text { residential stock could be retrofit each year). }\end{array}$ & $\begin{array}{l}\text { - FEMP budgets and programs } \\
\text { - DoD budgets and programs } \\
\text { - GSA budgets and programs } \\
\text { - EPACT, EISA, and the Executive } \\
\text { Orders and rules used to carry out } \\
\text { federal mandates will often refer to } \\
\text { Energy Star and NFRC-rated } \\
\text { products to guide energy-related } \\
\text { decision-making by federal facility } \\
\text { managers. }\end{array}$ \\
\hline $\begin{array}{l}\text { Applicable } \\
\text { commercial } \\
\text { stock }\end{array}$ & $\begin{array}{l}\text { - Approximately } 2 \% \text { of commercial building stock is } \\
\text { retrofit each year, low-e storm windows could find } \\
\text { point of entry during this natural renovation/retrofit } \\
\text { process with some level of outreach and education. }\end{array}$ & $\begin{array}{l}\text { - DOE's CBI team } \\
\text { - Overall transformation and } \\
\text { outreach efforts could influence } \\
\text { this market }\end{array}$ \\
\hline
\end{tabular}




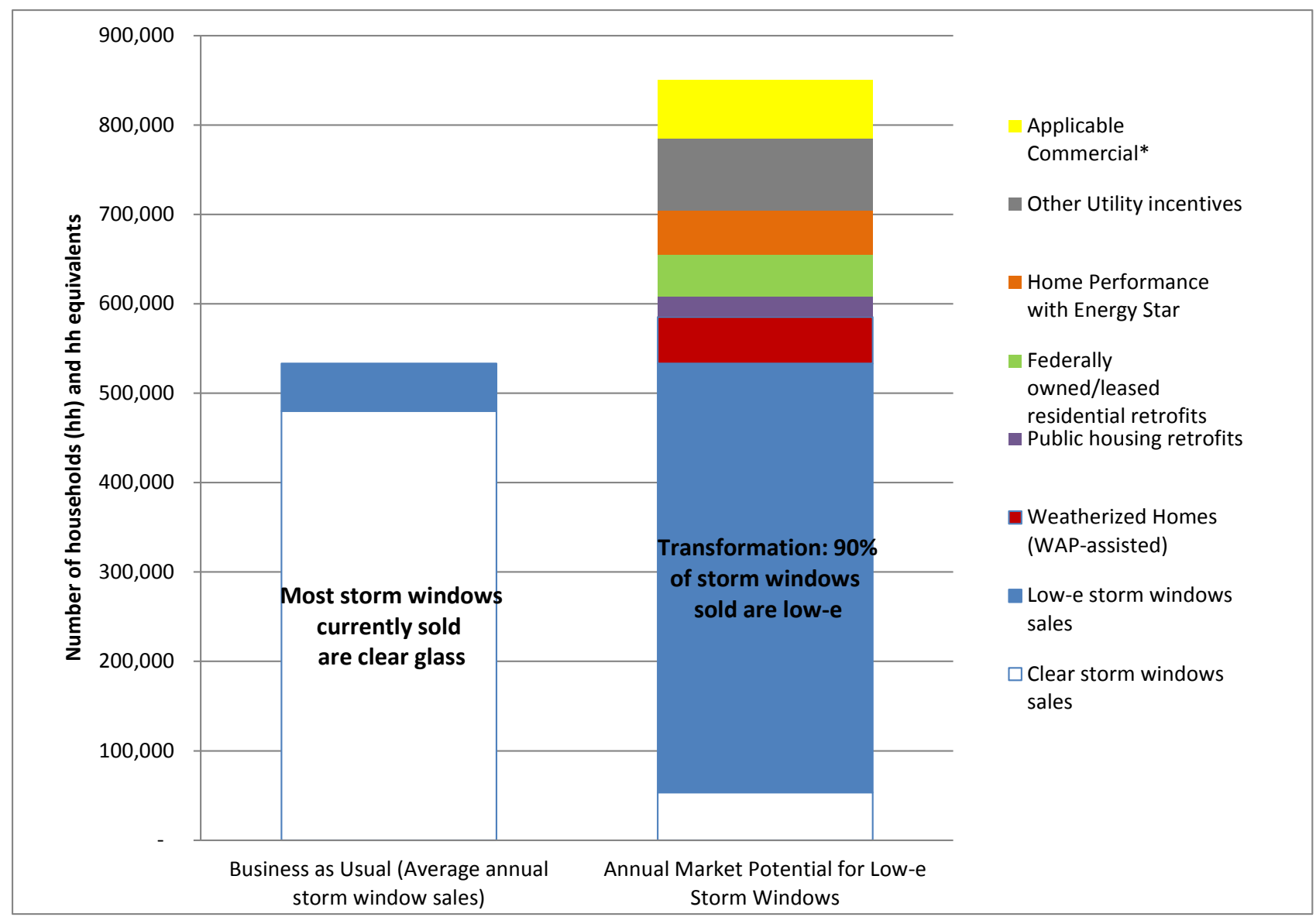

Figure 6.1. Estimated annual low-e window sales (by household) with and without market transformation

dealers, this will push retailers and dealers to become more familiar with the product and stock common sizes, which improves availability and the visibility of the technology to consumers. As the demand for low-e storm windows increases, more manufacturers who are currently only producing clear storm windows will be motivated to make the switch to low-e storm windows. On a small scale, this appears to be what occurred in Pennsylvania when it introduced low-e storm windows to its priority list of weatherization measures (see text box on Pennsylvania Weatherization Experience).

For low-e storm windows, the effective sales force for market transformation activities could include storm window manufacturers, installers, home performance contractors, FEMP, consortiums (e.g., CEE), Building America teams, BB teams, and Commercial Building Integration teams (see Figure 4.2).

Transformation activities directed toward one market segment can also influence other market segments. For example, an established weatherization program that includes low-e storm windows could lead to an abundance of installers and home performance contractors in a given region with low-e storm window installation experience and knowledge about the benefits of low-e storm windows. These installers and contractors then become a more effective sales force for low-e storm windows, enabling the inclusion of low-e storm window installations in general home performance upgrades and other utility-sponsored programs they support. 


\subsection{Energy Impacts}

As estimated in Section 3.3 of this report, if all single- and double-pane clear windows in the residential sector were covered with low-e storm windows, heating and cooling consumption could be reduced by an estimated 0.5 to 1.4 quadrillion Btus. This savings represents the technical potential of this technology. If these estimates are converted to source energy, the technical potential savings would range from 0.7 to 1.96 quadrillion Btus. To evaluate the market potential of low-e storm windows with and without market transformation, the size of the targeted market segments was considered along with the likelihood of transforming these markets by way of the pathways, programs, and activities identified in Table 6.1 and Figure 6.2. The results are illustrated with three market scenarios in the following section.

\section{Market Uptake Scenarios Potential}

To assess the potential overall energy savings of this technology, three market scenarios were developed to illustrate the range of savings: the moderate outlook scenario, optimistic outlook scenario, and the no market transformation scenario.

\section{Moderate Outlook Scenario}

The moderate outlook scenario is intended to capture the savings that could reasonably be achieved based on the assumption that the sales force identified in Figure 4.2 actively engages in deployment activities related to low-e storm windows. The scenario uses the current and expected funding levels for various programs identified as the core customers in Figure 4.2 and Table 6.2, including FEMP (as well as DOD) and WAP. The per-household HVAC savings level for low-e storm window installations is assumed to be $20 \%$ on average. To estimate moderate outlook savings, low-e storm window sales are projected to be integrated into most of the retrofits performed by HPwES that do not receive window replacements. HPwES is projected to continue at its current level of retrofits per year and utility programs are projected to expand such that more states include incentive programs related to energyefficient window attachments. Federal facilities' energy targets were assumed to keep pace with their current level of progress.

The primary (source) energy savings projections for the moderate case are included in Figure 6.3 for the years 2015, 2025, and 2035. The annual level of savings for the moderate outlook scenario for 2025 is approximately 140 trillion Btus of source/primary energy.

\section{Optimistic Outlook Scenario}

The optimistic outlook scenario assumes a higher level of household savings for low-e storms than the moderate outlook-increasing from 20\% HVAC savings on average to $30 \%$. It also assumes that WAP funding levels return to their pre-2010 annual levels (i.e., nearly four times greater than current budgets). The level of HPwES and utility-sponsored annual retrofits are also assumed to be $25 \%$ greater than in the moderate case. Federal facilities' energy targets are assumed to be met.

The primary (source) energy savings projections for the optimistic outlook case are included in Figure 6.3 for the years 2015, 2025, and 2035. The annual level of savings for the optimistic outlook scenario for 2025 is approximately 250 trillion Btus of source/primary energy. 


\section{No Market Transformation Scenario}

The no market transformation scenario assumes that DOE-supported market transformation activities for low-e storm window adoption do not continue. As noted in Figure 6.1, market adoption of this technology would continue; however, it would be limited to the traditional market for storm windows and the rate of adoption would be delayed by 3 years relative to the scenarios that include market transformation activities.

The primary (source) energy savings projections for the no market transformation case are included in Figure 6.2 for the years 2015, 2025, and 2035. The annual level of savings for the no market transformation scenario for 2025 is approximately 50 trillion Btus of source/primary energy.

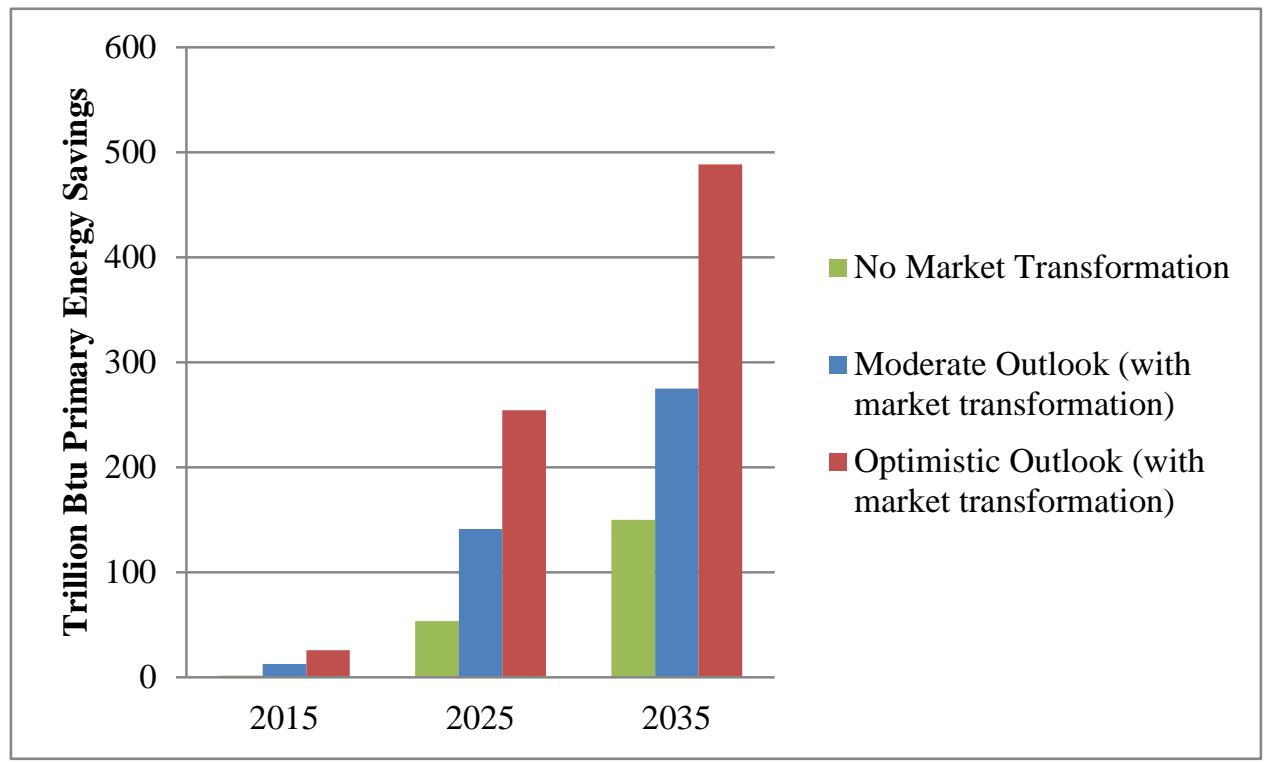

Figure 6.2. Energy savings for high, moderate, and low market scenarios 


\subsection{Conclusions}

Low-e storm windows appear to hold promise for effectively reducing existing home HVAC consumption. Due to the affordability of low-e storm windows and the large numbers of existing homes that have low-performing single-pane or double-pane clear windows, a tremendous opportunity exists to provide energy savings by transforming the low-e storm window market and increasing market adoption.

A number of promising market transformation pathways were identified, including existing weatherization assistance programs, utility energy-efficiency incentive programs, federally sponsored energy-efficiency retrofit programs geared toward existing residential buildings, standards and rating organizations, and federal building energy-efficiency mandates and programs. By working with storm window manufacturers, installers, energy-efficiency consortiums, and the Federal Energy Management Program, the Building America program could implement a number of targeted outreach, education, and technical assistance programs to effectively transform the market for low-e windows and have a measurable impact on reducing residential energy consumption over time. 


\subsection{References}

AAMA. 2012. "Window and Door Sales to Accelerate Next Year.” Window \& Door Magazine. Volume 20, Number 4, June/July 2012, - American Architectural Manufacturers Association.

Baylon, D, P Storm, K Geraghty, and B Davis. 2012. 2011 Residential Building Stock Assessment: "Single-Family Characteristics and Energy Use." September 18, 2012. Prepared by Ecotope, Inc. for the Northwest Energy Efficiency Alliance.

Cadmus. 2011. Michigan Baseline Study 2011: Residential Baseline Report. July 2011. Prepared by The Cadmus Group, Inc. for Michigan Public Service Commission.

DOE. 2011. Buildings Energy Data Book, U.S. Department of Energy Office of Energy Efficiency and Renewable Energy.Available on the web, at: http://buildingsdatabook.eren.doe.gov/DataBooks.aspx. U.S. Department of Energy.

DOE-EIA. 1993. 1993 Residential Energy Consumption Survey: Housing Characteristics. U.S. Department of Energy/Energy Information Administration.

DOE-EIA 2005. 2005 Residential Energy Consumption Survey: Housing Characteristics. U.S. Department of Energy/Energy Information Administration.

DOE-EIA. 2009. 2009 Residential Energy Consumption Survey: Housing Characteristics. U.S. Department of Energy/Energy Information Administration.

DOE-EIA 2003. 2003 Commercial Building Energy Consumption Survey. U.S. Department of Energy/Energy Information Administration.

DOE-EERE 2013. "Building America Technical Innovations Leading to 50\% Savings - A Critical Path.” Developed by NREL, Building America (BA) Standing Technical Committee Chairs and BA Team Technical Leads. April 17, 2013 (interim update).

Drumheller, SC, C Kohler, and S Minen. 2007. Field Evaluation of Low-e Storm Windows. LBNL-1940E, Lawrence Berkley National Laboratory, Berkeley, California.

Hefty MG and KA Cort. 2013. "Low-E Storm Window Adoption Program,” Building America Program Review. April 24-25, 2013. PNNL-SA-95081. Pacific Northwest National Laboratory.

Hefty, MG, TD Culp, and SH Widder. 2013. Task Plan in Support of Emerging Technology Task ETWIN-PNNL-FY13-01_5.1: Create a Database of U.S. Climate-Based Analysis for Low-E Storm Windows. PNNL-22307, Pacific Northwest National Laboratory, Richland, Washington.

Klems, JH. 2003. "Measured Winter Performance of Storm Windows,” ASHRAE Transactions 109(2), Paper KC-03-12-1, Lawrence Berkeley National Laboratory, Berkeley, California.

Krigger J and B Van der Meer, et al. 2011. Weatherization Standards and Field Guide for Pennsylvania. Published for the Department of Energy Weatherization Assistance Program and the Pennsylvania 
Department of Community, Economic Development, and Office of Energy Conservation and Weatherization. February 2011 Edition.

JCHS. 2013. The U.S. Housing Stock Ready for Renewal: Improving America's Housing 2013. Joint Center for Housing Studies of Harvard University.

Johnson Controls. 2010. “Johnson Controls 2010 Energy Efficiency Indicator North America Survey Results.” April 2010. Available online (May 2011) at http://johnsoncontrols.mediaroom.com/file.php/5496/Johnson+Controls_Energy+Efficiency+Indicator+2 $\underline{010+\text { North+America }}$

McKinsey \& Company. 2011. "Lighting the way: Perspectives on the global lighting market.” Editorial Staff: T. Baumgartner, F. Wunderlich, and D. Wee. Munich Office. Munich, Germany.

Parker GB, TS Mapes, and WJ Zalis. 2013. Highly Insulating Windows Volume Purchase Program Final Report. PNNL-22183, DOE/EE-0884. Pacific Northwest National Laboratory, Richland, Washington.

PNNL. 2012. A Business Case for Home Performance Contracting. Prepared by MC Baechler, CA Antonopoulos, M. Sevigny, TL Gilbride, MG Hefty. Pacific Northwest National Laboratory. October 2012. PNNL-21196.

Quanta Technologies. 2013. “2012-13 Quarterly Reports” prepared for U.S. Department of Energy under DOE EERE award \#DE-EE0004015.

USBC. 2012. American Housing Survey 2012. Table C-10-AO. U.S. Bureau of Census

Widder, S.2013. "Demonstration of Low-e Storm Windows in PNNL Lab Home: Experimental Plan Draft 3.” April 3, 2013. Unpublished document. Pacific Northwest National Laboratory.

Zalis W et al. 2010. Evaluation of Low-E Storm and R-5 Windows for Inclusion in Pennsylvania's Weatherization Priority List. Prepared by W Zalis, Energetics; T Culp, Birch Point Consulting; C Kohler, LBNL; and PM LaFrance, U.S. Department of Energy; for the Pennsylvania Department of Community and Economic Development, May 2010, Columbia, Maryland. 



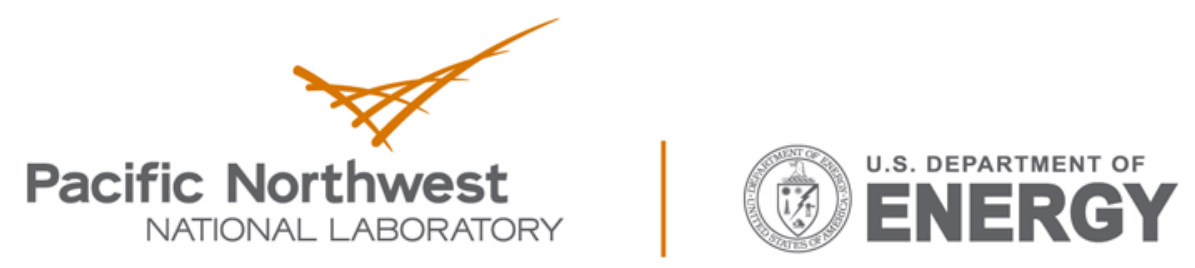

Proudly Operated by Battelle Since 1965

902 Battelle Boulevard

P.O. Box 999

Richland, WA 99352

1-888-375-PNNL (7665)

www.pnnl.gov 